\title{
Targeted Genome Engineering and Its Application in Trait Improvement of Crop Plants
}

\author{
Xiaoyu Yang1,2*, Linlin Luo', Beixin Mo', Lin Liu1* \\ ${ }^{1}$ Guangdong Provincial Key Laboratory for Plant Epigenetics, Longhua Bioindustry and Innovation Research Institute, \\ College of Life Sciences and Oceanography, Shenzhen University, Shenzhen, China \\ ${ }^{2}$ Key Laboratory of Optoelectronic Devices and Systems of Ministry of Education and Guangdong Province, \\ College of Optoelectronic Engineering, Shenzhen University, Shenzhen, China \\ Email: *xyyang-1982@163.com, *linliu@szu.edu.cn
}

How to cite this paper: Yang, X.Y., Luo, L.L., Mo, B.X. and Liu, L. (2019) Targeted Genome Engineering and Its Application in Trait Improvement of Crop Plants. Agricultural Sciences, 10, 1312-1342. https://doi.org/10.4236/as.2019.1010097

Received: September 19, 2019

Accepted: October 15, 2019

Published: October 18, 2019

Copyright (c) 2019 by author(s) and Scientific Research Publishing Inc. This work is licensed under the Creative Commons Attribution International License (CC BY 4.0).

http://creativecommons.org/licenses/by/4.0/

\begin{abstract}
Targeted genome engineering refers to technologies that are used for sitespecific genome modifications such as knockout, knockin and transcriptional regulation of genes of interest in organisms. Site-specific recombination system, zinc finger nucleases (ZFNs), transcriptional activator-like effector nucleases (TALENs) and clustered regularly interspaced short palindromic repeats (CRISPR)/CRISPR-associated protein-9 nuclease (Cas9) (CRISPR/Cas9) technologies are the representatives of targeted genome engineering and have been widely used in crop basic and applied research. In this review, we introduce the basic information and action modes of these different genome engineering technologies, summarize the recent progresses of targeted genome engineering technologies and their applications in crop improvement, and propose perspectives for genome engineering-mediated modifications of crop plants in the future.
\end{abstract}

\section{Keywords}

Targeted Genome Engineering, Site-Specific Recombination, ZFN, TALEN, CRISPR/Cas9, Crop Improvement

\section{Introduction}

In the past decades, global climate changes and improper agricultural practices have caused serious environmental problems such as soil salinization and acidification [1], soil erosion [2], drought [3] and explosion of insect pests [4], which severely challenge agricultural production in the world, while simultaneously the 
increasing of global crop productivity is required to meet the growing demand for grain products from continuously increased world population [5]. It becomes an urgent task for current agricultural scientists to create novel crop varieties with better agronomic traits such as high yield and grain quality, high nutrient usage efficiency, and good acclimation capacity to abiotic and biotic stresses. Conventional breeding strategies such as genetic hybridization have been widely used for creation of new crop varieties and obtained tremendous successes for a long period, but these processes are commonly time-consuming and labor-intensive, thus being difficult to satisfy modern plant breeding objectives.

The rapid development of molecular biology and transgene technologies has made it feasible to genetically modify the traits of interest, and lots of transgenic plants harboring beneficial agronomic traits such as golden rice, a kind of GM rice that is able to accumulate $\beta$-carotene in grain, have been generated [6] [7] [8]. In contrast to the widespread utilization of transgenic technology in the basic and applied research of crops in the lab, commercialization of GM crops is still strictly regulated by governments in the world such as China, Japan and European countries because of intensive concerns about biosafety of GM crops [9]. Therefore, only a very small portion of GM crops have been released by now [10] [11] [12] [13].

Targeted genome engineering refers to technologies that are used for sitespecific genome modifications including gene knockout, knockin and transcriptional regulation [14] [15]. Site-specific recombination system, ZFNs, TALENs and CRISPR/Cas9 technologies are the representatives of targeted genome engineering. In comparison to the conventional transgenic technology, genome editing has obvious advantages such as easy design and construction, high precision and efficiency of modifications for genome loci responsible for traits of interest, being capable of stacking multiple genes of interest simultaneously, generation of descendants without transgenic elements, and so on. Therefore, targeted genome engineering has attracted extensive attentions from plant scientists and breeders, and has been rapidly adopted in crop improvement, especially with the emergence of CRISPR/Cas9 system since 2013 [16] [17]. In this review, we summarize recent progresses of targeted genome engineering and its application in genetical modifications of crop plants, and propose perspectives for future research on genome editing-based crop improvement.

\section{Site-Specific Recombination System}

Site-specific recombination refers to the reaction of two DNA molecules catalyzed by specific enzymes (recombinases) at their cognate pairs of sequences or target sites [18]. This recombination requires three components, a recombinase such as Cre responsible for DNA editing and two DNA partners such as LoxP cognate sites recognized by the recombinase. The recombinases can be divided into two families, tyrosine recombinase family and serine recombinase family 
(Table 1) [18]. The tyrosine recombinases contain a conserved tyrosine active site and catalyze DNA rearrangement via formation and resolution of a Holliday junction intermediate [19], while the serine recombinases contain a conserved serine active site and catalyze site-specific DNA recombination through a concerted, four-strand cleavage and rejoining mechanism [20].

Among these site-specific recombination systems, Cre/LoxP is the most commonly used one, which is composed of Cre recombinase and 34-bp LoxP sequences that can be recognized by Cre [21]. When the Cre recombinase is expressed, recombination events will occur to the cells harboring LoxP recognition sites in their genomes. In general, there are three possible outcomes from the Cre/LoxP-derived recombination including inversion, translocation or excision, depending on the initial arrangement of LoxP recombination sites (Figure 1). Inversion event or excision event can occur when the recombination sites are located on the same chromosome with the same orientation or the opposite orientation, respectively. Translocation event can result from the exchange of DNA segments when the two recombination sites are located on separate chromosomes with the same orientation [21].

There are two main applications of site-specific recombination system in genetical modifications of crop plants: removal of undesirable transgenic elements such as selectable marker genes and site-specific integration of genes of interest. For example, by using Cre/LoxP-mediated recombination, the selectable maker gene, $H P T$, has been successfully eliminated from transgenic mustard plants with insect resistance [22]. Elimination of selectable marker genes has also been reported in rice [23], potato [24], tomato [25] and so on. Cre/LoxP system has been adopted in construction of maize and rice minichromosomes as well, wherein genes of interest are expected to be stacked without limitations [26] [27]. The application of Flp/Frt recombination system has also been reported for elimination of selectable marker genes in plants such as rice [28] and maize [29]. The representative GM crops that were generated via site-specific recombination recently are summarized in Table 2 .

Although targeted genome editing has been realized via different site-specific recombination tools, there are still disadvantages limiting their applications in current crop improvement such as the failure of complete removal of transgenic elements, complicated design for vectors, time-consuming multiple transformation and genetic hybridization, and relatively low targeting efficiency [52].

Table 1. Representative recombinases responsible for site-specific recombination [18].

\begin{tabular}{cl}
\hline \multicolumn{1}{c}{ Recombinase family } & \multicolumn{1}{c}{ Representative } \\
\hline \multirow{2}{*}{ Tyrosine recombinase family } & $\begin{array}{l}\text { Cre, Flp, R, } \lambda \text { Int, Int of Tn916/Tn1545, IntI, XerC/D, } \\
\text { TnpI of Tn4430, FimB/E, Rci of R64, XisA/C }\end{array}$ \\
& Cin or Gin, Int of $\varphi \mathrm{C} 31 / \mathrm{Bbv1/} \varphi \mathrm{Rv} 1, \mathrm{TnpR}$ of Tn3/ $\gamma$, \\
Serine recombinase family & Sin of $S$. aureus, ParA of RP4, Hin, OrfA of IS607/IS1535, \\
& TnpX of Tn4451, SpoIVCA, XisF \\
\hline
\end{tabular}



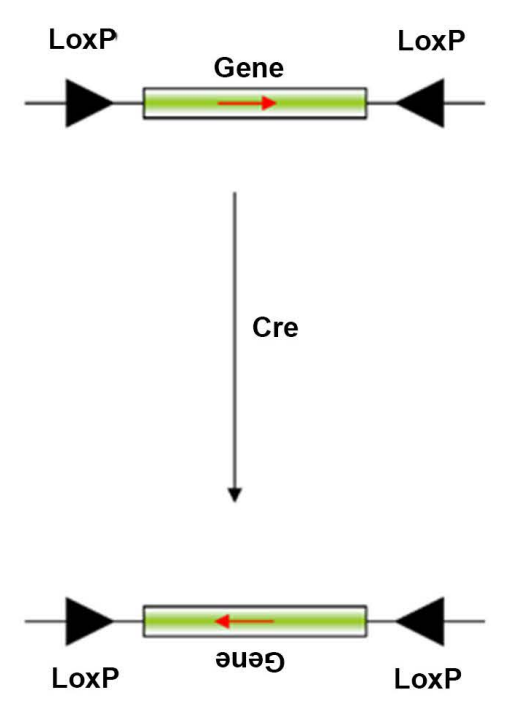

(a)

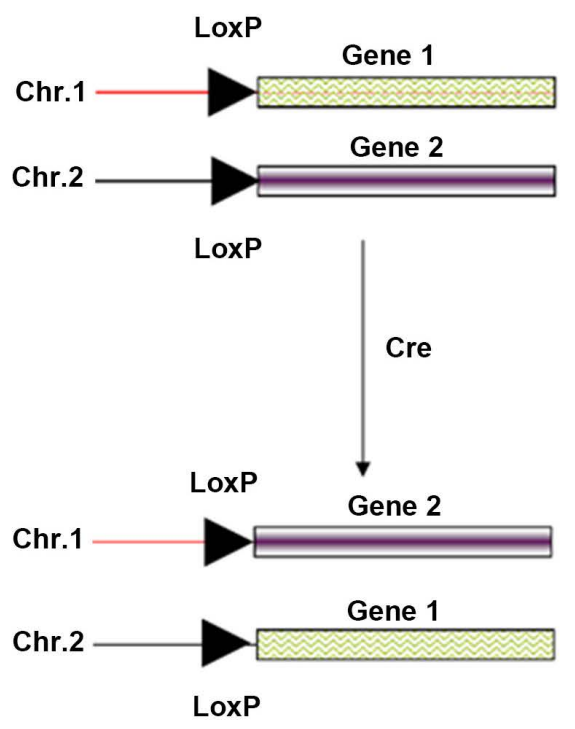

(b)
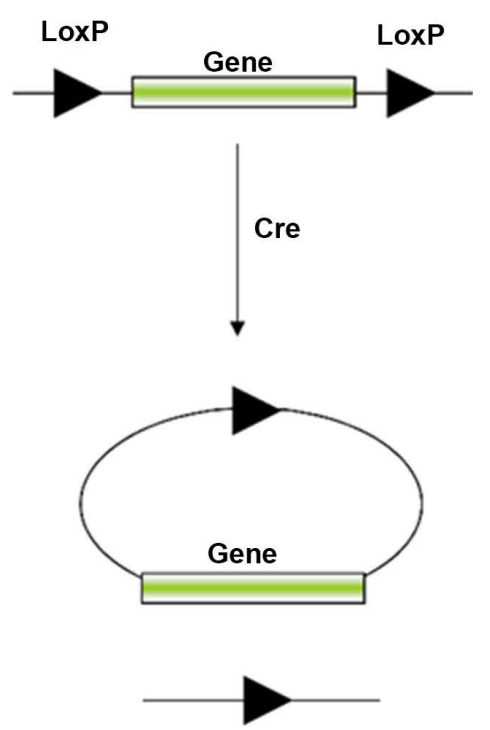

(c)

Figure 1. Cre/LoxP-mediated site-specific recombination. (a) Cre/LoxP-mediated inversion event can occur when two LoxP sites are located on the same chromosome with opposite orientation. (b) Cre/LoxP-mediated translocation event can occur when two LoxP sites are located on separate chromosomes with the same orientation. (c) Cre/LoxP-mediated excision event can occur when two LoxP sites are located on the same chromosome with the same orientation.

\section{ZFN Technology}

ZF proteins are the common group of DNA binding proteins in eukaryotic organisms. Each ZF protein is composed of about 30 amino acids in a conserved $\beta-\beta-\alpha$ configuration [53]. The DNA binding ability is determined by the specific amino acids present on the surface of the $\alpha$-helix in each ZF with varying specificity. Based on the specific DNA binding trait, a targeted genome editing platform, ZFNs, has been constructed (Figure 2). A ZFN system is composed of two arrays of ZF proteins and a nuclease such as Fok I. Each array of ZF proteins is linked with a subunit of Fok I. Fok I can work normally after the two arrays of ZF proteins bind to the DNA sites of interest and two subunits of Fok I are dimerized. There are several strategies used for the assembly of ZFNs. The first one is called as modular assembly, a strategy based on the library of ZFs with well-known DNA-binding specificities. ZFNs can also be assembled through webbased tools by combining random assembly of multi-finger libraries with specificity screening or by companies.

In general, there are two types of DNA editing by ZFNs (Figure 2). The first type is the targeted gene knockout, of which the purpose is to create a null mutant by interfering with the expression of genes of interest at DNA level. For example, the HIV-1 resistance has been detected in the primary T cells and the hematopoietic stem/progenitor cells by ZFN-mediated knockout of the $C C$ chemokine receptor 5 [54] [55]. A maize ipk1 mutant line has also been generated by ZFN-mediated gene knockout, leading to a modified phytate biosynthesis pathway in the resulted maize plants [56]. The other is the targeted gene 
Table 2. The application of site-specific recombination system in targeted gene modifications of crop plants.

\begin{tabular}{|c|c|c|c|c|c|}
\hline $\begin{array}{l}\text { Modification } \\
\text { type }\end{array}$ & Crop & System & Target & Purpose & Reference \\
\hline \multirow{17}{*}{$\begin{array}{l}\text { Removal of } \\
\text { transgenic } \\
\text { elements }\end{array}$} & Apple & Flp/Frt & NPTII, RVI6 & $\begin{array}{l}\text { Marker gene excision, } \\
\text { scab resistance }\end{array}$ & {$[30]$} \\
\hline & Barley & phiC31 & $G F P$ & Excision assessment & {$[31]$} \\
\hline & Barley & Cre/LoxP & $B A R$ & Marker gene excision & {$[32]$} \\
\hline & Grapevine & Flp/Frt & NPTII & Marker gene excision & [33] \\
\hline & Maize & Cre/LoxP & $G A T, C F P$ & Excision assessment & {$[34]$} \\
\hline & Maize & Cre/LoxP & $G F P$ & Marker gene excision & {$[35]$} \\
\hline & Mustard & Cre/LoxP & $H P T$ & Marker gene excision & {$[22]$} \\
\hline & $\begin{array}{l}\text { Oilseed } \\
\text { rape }\end{array}$ & Cre/LoxP & NPTII & Marker gene excision & {$[36]$} \\
\hline & Orange & Cre/LoxP & $A A T C B, I P T$ & $\begin{array}{l}\text { Canker resistance, marker } \\
\text { gene excision }\end{array}$ & [37] \\
\hline & Potato & Cre/LoxP & $B A R$ & Marker gene excision & {$[38]$} \\
\hline & Rice & Cre/LoxP & NOS terminator & $\begin{array}{l}\text { Transgenic element } \\
\text { excision }\end{array}$ & [39] \\
\hline & Rice & Flp/Frt & $H P T, T C$ & $\begin{array}{l}\text { Enhancement of } \\
\text { tocopherol content, } \\
\text { marker gene excision }\end{array}$ & {$[40]$} \\
\hline & Soybean & Cre/LoxP & NPTII & Marker gene excision & {$[41]$} \\
\hline & Tobacco & Cre/LoxP & $N P T I I$ & Marker gene excision & {$[42]$} \\
\hline & Tobacco & CinH-RS2 & $G F P$ & Excision assessment & {$[43]$} \\
\hline & Tobacco & $\begin{array}{l}\text { ParA-MRS, } \\
\text { CinH-RS2 }\end{array}$ & $R F P$ & Marker gene excision & {$[44]$} \\
\hline & Wheat & Cre/LoxP & $B A R$ & Marker gene excision & {$[45]$} \\
\hline \multirow{7}{*}{$\begin{array}{l}\text { Gene } \\
\text { integration }\end{array}$} & Maize & Cre/LoxP & $R F P$ & Insertion assessment & {$[26]$} \\
\hline & Maize & Flp/Frt & $P M I, R F P$ & Insertion assessment & {$[46]$} \\
\hline & $\begin{array}{l}\text { Oilseed } \\
\text { rape }\end{array}$ & $\begin{array}{l}\text { Cre/LoxP, } \\
\text { Flp/Frt }\end{array}$ & $R F P, G F P$ & Insertion assessment & {$[47]$} \\
\hline & Rice & Cre/LoxP & GUS & Insertion assessment & {$[48]$} \\
\hline & Rice & $\begin{array}{l}\text { Cre/LoxP, } \\
\text { ZFN }\end{array}$ & $\begin{array}{l}\text { UBI promoter, } \\
\text { clone sites for } \\
\text { genes of interest }\end{array}$ & Insertion assessment & [49] \\
\hline & Soybean & Flp/Frt & $A L S, C F P$ & Insertion assessment & {$[50]$} \\
\hline & Tobacco & $\mathrm{R} / \mathrm{Rs}$ & LUC & Insertion assessment & {$[51]$} \\
\hline
\end{tabular}

knockin, of which the purpose is to create organisms expressing genes of interest by introducing exogenous genes at a specific site of the genome or by repairing the mutation sites of endogenous genes. In this case, for example, ZFNs have been applied to repair the mutation sites that are closely associated with diseases such as haemophilia B [57], sickle-cell disease [58] and Parkinson's disease [59]. In tobacco BY2 cells, a functional GFP gene has been successfully introduced into both the pre-integrated defective reporter construct and an endogenous locus 
(a)

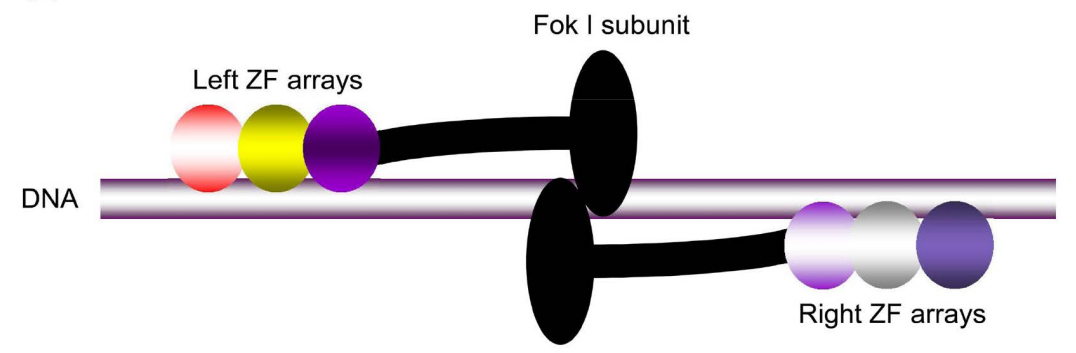

Fok I subunit

(b)

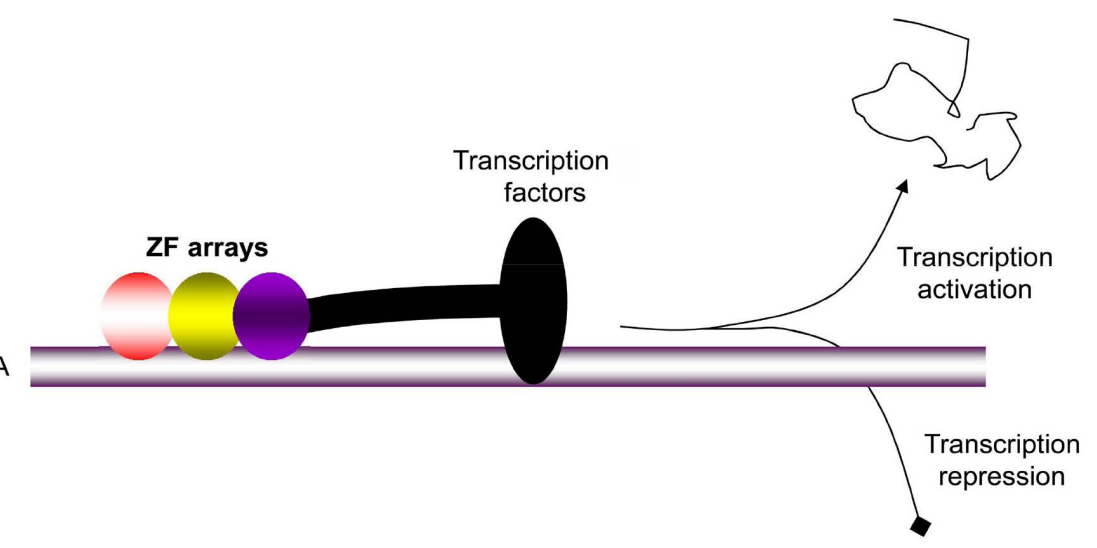

Figure 2. Zinc finger (ZF)-mediated regulation of gene expression. (a) ZF nuclease (ZFN)-mediated genome editing. Arrays of ZF proteins recognize specific DNA sequences in the genome, and double-strand breakages (DSBs) will be generated by linked Fok I nuclease. The DSBs will be repaired by either non-homologous end joining (NHEJ) to produce knockout events or by homologous recombination (HR) to produce gene knockin events. (b) ZF-mediated transcriptional regulation of gene expression. By linking with specific transcription factors or repressors, ZFs can also be used to regulate gene expression at transcriptional level.

by ZFNs [60]. In addition to the targeted gene knockout and knockin, ZFs can be linked with transcriptional factors to regulate gene expression at DNA level [61]. Table 3 shows a summary of representative GM crops that were generated via $\mathrm{ZFN}$ system recently.

Despite the successes of ZF-associated technologies in previous studies, some disadvantages such as the complexity of assembly, context-dependent binding specificity and relatively low targeting efficiency have not been well addressed and thus limited the application of these technologies in current research [74].

\section{TALEN Technology}

TALEs are a group of natural proteins from the genus of plant bacteria, Xanthomonas, and can bind some specific DNA regions in plant genome through a series of 33-35 amino acid domains that each can recognize a single base pair [75]. The binding specificity of TALEs is dependent on the RVD, the two highly-variable amino acids at the position of 12 and 13 in each TALE (Table 4) [75]. TALEs can be designed to recognize specific DNA sequences in the genome. By 
Table 3. The application of zinc finger nucleases (ZFNs) or ZF transcription factors in targeted gene modifications of crop plants.

\begin{tabular}{|c|c|c|c|c|}
\hline Modification type & Crop & Target & Purpose & Reference \\
\hline \multirow{7}{*}{ Knockout } & Apple & GUS & Mutagenesis assessment & {$[62]$} \\
\hline & Fig & GUS & Mutagenesis assessment & {$[62]$} \\
\hline & Maize & IPK1 & $\begin{array}{l}\text { Alteration of inositol } \\
\text { phosphate profile }\end{array}$ & [56] \\
\hline & Poplar & $L F Y, A G$ & Complete sexual sterility & [63] \\
\hline & Tobacco & $S U R$ & Herbicide resistance & {$[64]$} \\
\hline & Tobacco & GUS & Transgene disruption & {$[65]$} \\
\hline & Soybean & $\begin{array}{c}D C L 1 a, D C L 1 b, D C L 4 a \\
D C L 4 b\end{array}$ & Mutagenesis assessment & [66] \\
\hline \multirow{7}{*}{ Knockin } & Maize & $P A T$ & Herbicide resistance & [56] \\
\hline & Maize & $A A D 1$ & Herbicide resistance & [67] \\
\hline & Maize & $P A T$ & Herbicide resistance & [68] \\
\hline & Maize & $B A R$ & Herbicide resistance & [69] \\
\hline & Rice & GUS & $\begin{array}{c}\text { Identification of safe } \\
\text { harbor loci }\end{array}$ & {$[70]$} \\
\hline & Soybean & $\begin{array}{c}A A D 1, D S M 2, D G T 28 \\
H P T I I, R P F\end{array}$ & $\begin{array}{l}\text { Multigene insertion } \\
\text { assessment }\end{array}$ & {$[71]$} \\
\hline & Tobacco & NPTII, RFP & Insertion assessment & {$[72]$} \\
\hline $\begin{array}{c}\text { Transcription } \\
\text { activation }\end{array}$ & $\begin{array}{l}\text { Oilseed } \\
\text { rape }\end{array}$ & $K A S I I$ & $\begin{array}{l}\text { Improvement of oil } \\
\text { production }\end{array}$ & [73] \\
\hline
\end{tabular}

Table 4. The corresponding nucleotide of amino acid pairs in transcriptional activator-like effector (TALE) [75].

\begin{tabular}{cc}
\hline RVD in TALE & The corresponding nucleotide \\
\hline NI (Asparagine and Isoleucine) & $\mathrm{A}$ \\
HD (Histidine and Aspartate) & $\mathrm{C}$ \\
NN (Asparagine and Asparagine) & $\mathrm{G} / \mathrm{A}$ \\
NG (Asparagine and Glycine) & $\mathrm{T}$ \\
\hline
\end{tabular}

adding a nuclease such as the Fok-I, TALEN system has been developed to make DSBs on pre-selected genome sites to generate knockout or knockin editing in the genome (Figure 3).

For example, AvrXa7 is the effector-binding element in the promoter of a bacterial blight susceptibility gene Os11N3, and the TALEN-mediated knockout of this element has generated rice with resistance to bacterial blight [76]. In another report, rice fragrance has been improved by TALEN-mediated targeting to a defective badh2 allele, which is responsible for the synthesis of 2AP, a major fragrance compound in rice [77]. The TALE designer transcription factors have been used to regulate OCT4 and NANOG loci by targeting their enhancers in mammalian cells, leading to stimulation or inhibition of reprogramming somatic cells to the induced pluripotent cells [78], while similar applications have not been introduced into plants yet. Table 5 shows a summary of representative GM crops that were generated via TALEN recently. 

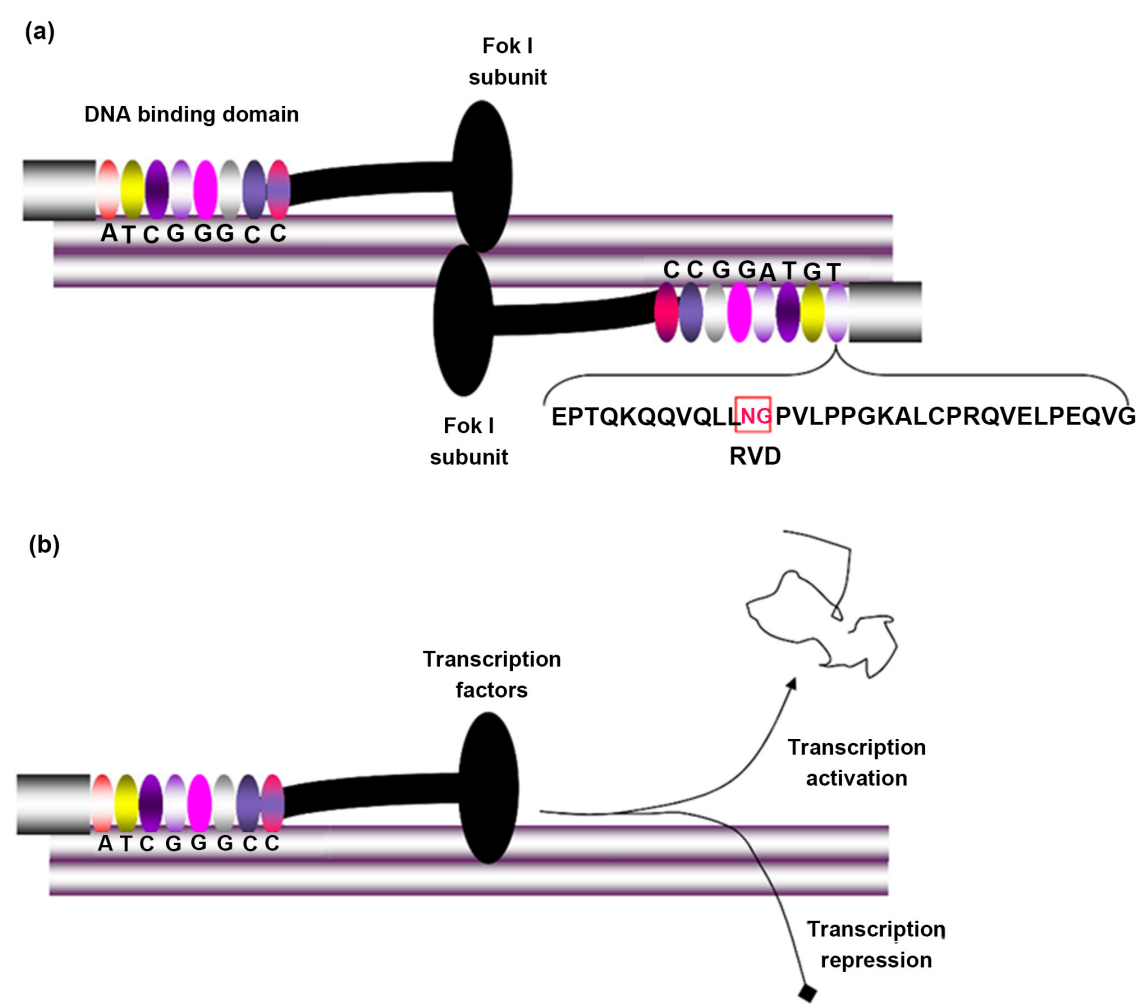

Figure 3. Transcription activator-like effector (TALE)-mediated regulation of gene expression. (a) TALE nuclease (TALEN)-mediated gene knockout event based on nonhomologous end joining (NHEJ) mechanism or gene knockin event based on homologous recombination (HR) mechanism. (b) TALE-mediated transcriptional regulation of gene expression. By linking with specific transcription factors, TALEs can also be used to regulate gene expression transcriptionally. The binding specificity of each TALE is dependent on repeat-variable di-residue (RVD) composition.

The single base recognition of TALE-DNA binding repeats affords greater design flexibility than triplet-confined ZF proteins, while the assembly of the large repetitive TALE modules is still a great challenge for the cloning of repeated TALE arrays [74].

\section{CRISPR/Cas9 System}

CRISPR/Cas is an adaptive innate immune system to defend against the invasion of viral and plasmid DNA in bacteria and archaes [99]. Scientists have found three types of CRISPR/Cas systems (type I, II and III) within a series of microbes, and each type includes a Cas protein and the corresponding CRISPR arrays [100]. These CRISPR/Cas arrays are composed of repeat sequences interspaced by spacer sequences, which are non-repetitive and derive from the short segments of viral or plasmid DNA often called as protospacer sequences. By transcribing the CRISPR arrays into crRNAs, Cas proteins can be directed to the target sites and make DSBs, resulting in the degradation of foreign genetic materials. 
Table 5. The application of transcription activator-like effector nuclease (TALEN) technology in targeted gene modifications of crop plants.

\begin{tabular}{|c|c|c|c|c|}
\hline $\begin{array}{l}\text { Modification } \\
\text { type }\end{array}$ & Crop & Target & Purpose & Reference \\
\hline \multirow{17}{*}{ Knockout } & $\begin{array}{l}\text { Brassica } \\
\text { oleracea }\end{array}$ & FRI & Mutagenesis assessment & {$[79]$} \\
\hline & Maize & GL2 & Alteration of wax compositions & [80] \\
\hline & Maize & $M T L$ & Haploid induction & [81] \\
\hline & Peanut & FAD2 & Alteration of lipid compositions & {$[82]$} \\
\hline & Potato & SSR2 & Inhibition of cholesterol synthesis & {$[83]$} \\
\hline & Potato & $A L S 1$ & Mutagenesis assessment & [84] \\
\hline & Potato & $V I N V$ & Reduction of acrylamide content & {$[85]$} \\
\hline & Potato & SBE1, VINV & $\begin{array}{l}\text { Alterations of starch compositions and } \\
\text { cold sweetening trait }\end{array}$ & {$[86]$} \\
\hline & Rice & $11 N 3$ & Bacterial blight resistance & {$[76]$} \\
\hline & Rice & $B A D H 2$ & Improvement of grain fragrance & {$[77]$} \\
\hline & Rice & $11 N 3$ & Bacterial blight resistance & {$[87]$} \\
\hline & Sugarcane & $C O M T$ & Alteration of cell wall composition & {$[88]$} \\
\hline & Sugarcane & $C O M T$ & Alteration of cell wall composition & [89] \\
\hline & Soybean & $F A D 2-1 a, F A D 2-1 b$ & Alteration of lipid compositions & {$[90]$} \\
\hline & Soybean & $\begin{array}{c}\text { FAD2-1a, } \\
\text { FAD2-1b, FAD3a }\end{array}$ & Alteration of lipid compositions & {$[91]$} \\
\hline & Tobacco & $A L S$ & Mutagenesis assessment & {$[92]$} \\
\hline & Wheat & $M L O$ & Powdery mildew resistance & [93] \\
\hline \multirow{6}{*}{ Knockin } & Barley & $G F P$ & Insertion assessment & {$[94]$} \\
\hline & Potato & $A L S 1$ & Herbicide resistance & [95] \\
\hline & Potato & $A L S, N P T I I$ & $\begin{array}{l}\text { Insertion assessment, herbicide } \\
\text { resistance }\end{array}$ & {$[96]$} \\
\hline & Rice & $A L S$ & Herbicide resistance & [97] \\
\hline & Tobacco & $Y F P$ & Insertion assessment & {$[92]$} \\
\hline & Tomato & $35 \mathrm{~S}$ promoter & Anthocyanin accumulation & [98] \\
\hline
\end{tabular}

Among the three CRISPR systems, the type II CRISPR system is the first one to be engineered for targeted genome editing in eukaryotic organisms (Figure 4). In this system DNA sequence bearing a 5'-NGG-3' PAM can be recognized by a duplex of two non-coding RNAs, a crRNA and a tracrRNA, or with a sgRNA, which is a synthetic fusion of crRNA and tracrRNA, and then be degraded by Cas9 protein that is complexed with the duplex of crRNA and tracrRNA or the sgRNA [16] [17]. The Cas9 protein from Streptococcus pyogenes (SpCas9) has two nuclease motifs, $\mathrm{HNH}$ and RuvC, which play critical roles in generating DSBs at target sites [101]. The target specificity of CRISPR/Cas9 is determined by a seed sequence, which is a 12-base sequence upstream of the PAM and must match with the sequence of crRNA or sgRNA [102]. Compared with the 


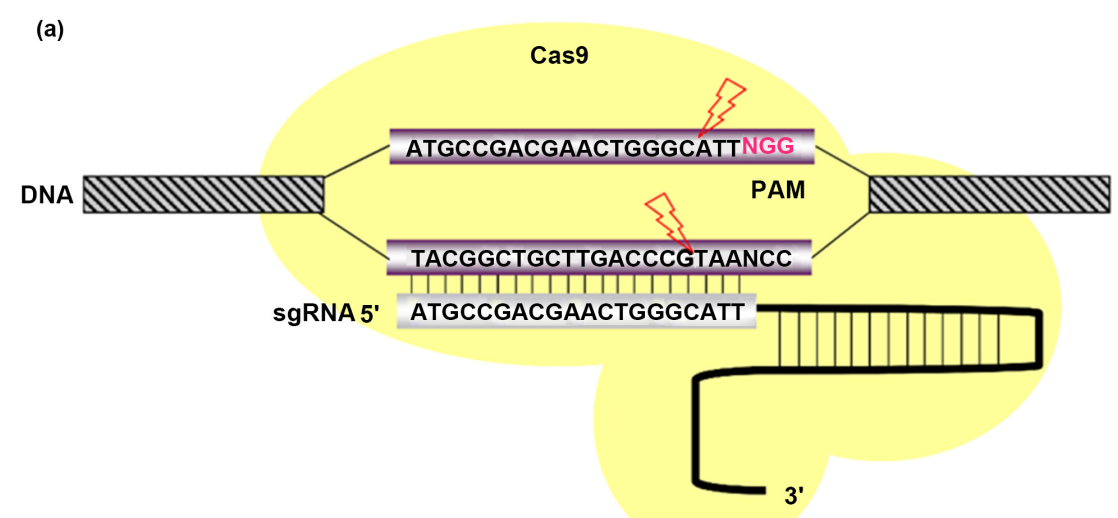

(b)

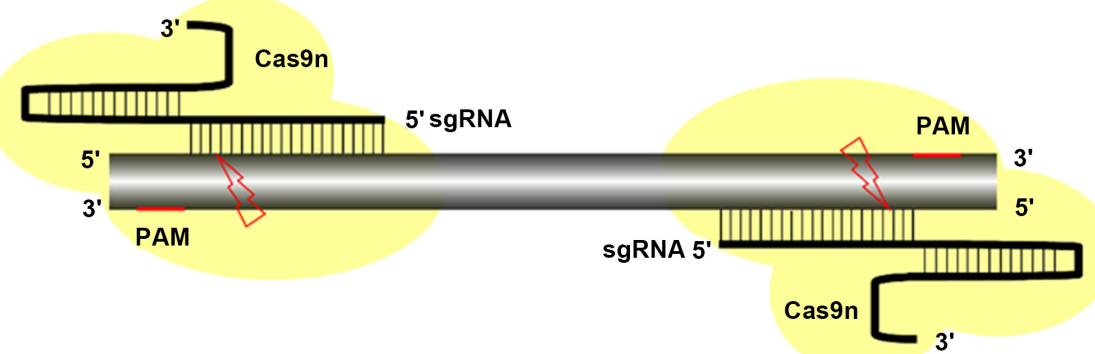

(c)

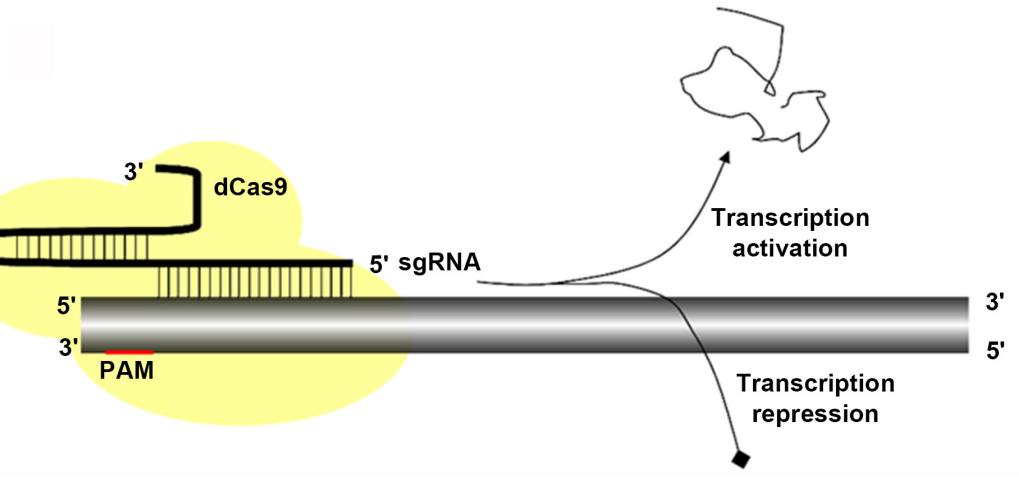

Figure 4. The basic components of a clustered regularly interspaced short palindromic repeats (CRISPR)/CRISPR-associated protein-9 nuclease (Cas9) (CRISPR/Cas9) system and its application in targeted genome editing. (a) CRISPR/Cas9 or (b) CRISPR/Cas9nmediated gene knockout event based on non-homologous end joining (NHEJ) mechanism or gene knockin event based on homologous recombination (HR) mechanism after the occurrence of Cas9 or Cas9n-induced double-strand breakages (DSBs). (c) CRISPR/dCas9mediated transcriptional regulation of gene expression. By being fused with specific transcription factors, dCas 9 can regulate gene expression transcriptionally via RNA-directed binding to specific genome sites. Targeted gene repression can also be realized via the only dCas9 associated with specific sgRNAs. The binding specificity of CRISPR/Cas9 system is dependent on a seed sequence, which is an about 12-base sequence upstream of the PAM sequence and must match with the crRNA or sgRNA.

formerly-designed ZFNs and TALENs, CRISPR/Cas9 system has more advantages such as the simplicity of design and assembly, the high efficiency of targeting and the versatility of application, and thus is expected to be a powerful tool for targeted genome editing (Table 6). 
Table 6. Characteristic comparison of different targeted genome engineering systems.

\begin{tabular}{|c|c|c|c|c|c|}
\hline & Cre/LoxP & Flp/Frt & ZFN & TALEN & CRISPR/Cas9 \\
\hline Design and assembly & Easy & Easy & Difficult & Difficult & Easy \\
\hline Targeting site & $34 \mathrm{bp}$ & $34 \mathrm{bp}$ & $\begin{array}{l}9-18 \mathrm{bp} \text { for } \mathrm{ZFN} \\
\text { monomer, } 18-36 \mathrm{bp} \\
\text { for ZFN dimer }\end{array}$ & $\begin{array}{l}14-20 \text { bp for TALEN } \\
\text { dimer, } 28-40 \text { bp for } \\
\text { TALEN dimer }\end{array}$ & $\begin{array}{l}23 \mathrm{bp} \text { including } 20 \mathrm{bp} \text { binding } \\
\text { site and } 3 \mathrm{bp} \text { PAM, multiple } \\
\text { editing simultaneously }\end{array}$ \\
\hline $\begin{array}{l}\text { Restriction for target } \\
\text { sites on genome }\end{array}$ & High & High & No & No & Low \\
\hline $\begin{array}{l}\text { Mismatch tolerance } \\
\text { at target site }\end{array}$ & No & No & Low & Low & Relatively high \\
\hline Targeting efficiency & Low & Low & Low & Moderate & High \\
\hline Repair mechanism & HR & HR & NHEJ and HR & NHEJ and HR & NHEJ and HR \\
\hline Off-target effects & $\begin{array}{l}\text { Not } \\
\text { available }\end{array}$ & $\begin{array}{l}\text { Not } \\
\text { available }\end{array}$ & Low & Low & Low \\
\hline $\begin{array}{l}\text { Transgene-free in } \\
\text { offspring }\end{array}$ & No & No & Yes & Yes & Yes \\
\hline
\end{tabular}

CRISPR/Cas9 is first reported to be efficient in targeted genome editing in mammalian cells at single-gene level [16] [17], multi-gene level [103] and even genome-wide level [104]. Thereafter, this system is adopted for gene knockout or knockin in plants such as Arabidopsis, tobacco, sorghum, rice, and wheat [105] [106]. By modifying two amino acids at the position of 10 and 841 from aspartate $(\mathrm{D})$ and histidine $(\mathrm{H})$ to alanine $(\mathrm{A})$, scientists have successfully developed two variants of Cas9, Cas9n (D10A) with a nickase activity and dCas9 (D10A and $\mathrm{H} 841 \mathrm{~A}$ ) without any catalytic activity. The two variants of Cas9 have been further developed to CRIPSR/Cas9n [107] and CRISPR/dCas9 systems [108]. Some Cas9-derived base editor systems have also been established by fusing an adenine or a cytidine deaminase to a Cas9n protein [109]. Being different from the classical Cas9 system, the base editor systems can catalyze two kinds of nucleotide replacement reactions, from adenine (A) to guanine (G) or from cytosine (C) to thymine (T), depending on the deaminase that is linked to Cas9n [109]. Applications of these Cas9-derived systems have been reported in targeted genome editing. For example, in a comparison study of gene expression regulation by CRISPR/dCas9 and TALE designer transcription factor systems, scientists have demonstrated better performance in activation of gene expression by TALE activator system, while repression by CRISPR/dCa9 was similar with or better than TALE repressor [78]. The successful utilization of base editors has been well documented in crop plants such as rice, tomato, potato, wheat, maize, rape and watermelon as well [110]-[118]. To date, CRISPR/Cas9-mediated genome editing has been widely used for crop improvement and a number of GM crops with desired traits have been created (Table 7).

Recently, some orthologues of the classical Cas9 (SpCas9) have been identified in bacteria such as SaCas9 from Staphylococcus aureus and St1Cas9 from Streptococcus thermophilus [154], and been adopted in targeted genome modifications 
Table 7. The application of CRISPR/Cas9 in targeted gene modifications of crop plants.

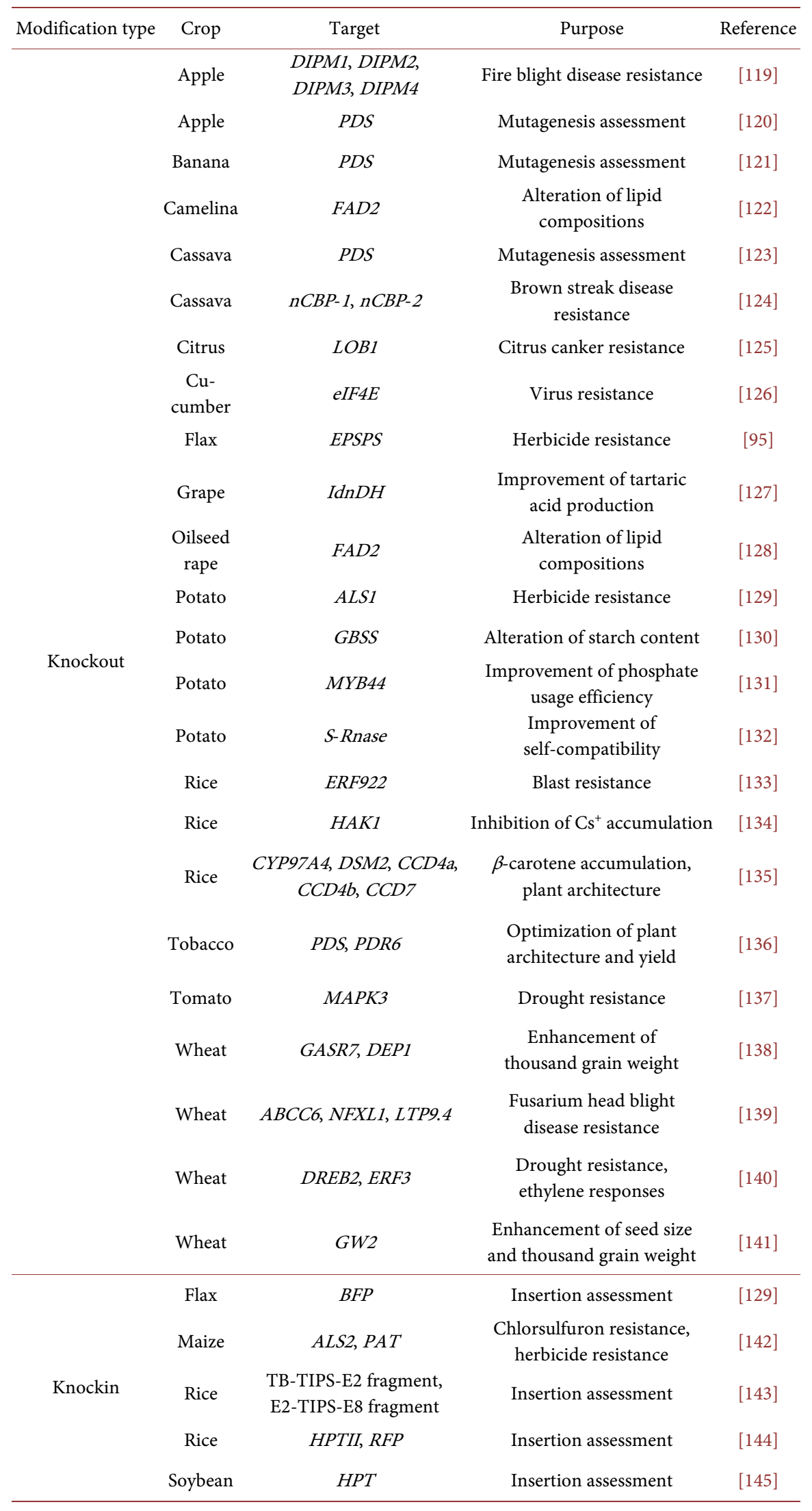


Continued

\begin{tabular}{|c|c|c|c|c|}
\hline \multirow{3}{*}{ Knockin } & Tobacco & AvrII recognition site & Insertion assessment & [146] \\
\hline & Tomato & $A L S 2$ & Chlorsulfuron resistance & [147] \\
\hline & Wheat & $G F P$ & Insertion assessment & [148] \\
\hline \multirow{5}{*}{$\begin{array}{c}\text { Transcriptional } \\
\text { activation }\end{array}$} & Rice & $G W 7, E R 1$ & Activation assessment & [149] \\
\hline & Rice & $\begin{array}{c}\text { Os03go1240, Os04g39780, } \\
\text { Os11g35410 }\end{array}$ & Activation assessment & [150] \\
\hline & Tobacco & PDS & Activation assessment & [151] \\
\hline & Tobacco & GUS & Activation assessment & [152] \\
\hline & Tobacco & $L U C$ & Activation assessment & [153] \\
\hline \multirow{2}{*}{$\begin{array}{l}\text { Transcriptional } \\
\text { repression }\end{array}$} & Tobacco & PDS & Repression assessment & [151] \\
\hline & Tobacco & $L U C$ & Repression assessment & [153] \\
\hline
\end{tabular}

of Arabidopsis, tobacco and rice (Table 8) [155] [156]. The comparable target efficiency of SaCas9 and St1Cas9 with SpCas9 system has also been documented in plants [155]. Although all of the three Cas9 proteins are clustered to the type II CRISPR/Cas system, different PAM sequences are recognized (5'-NNGRRT-3' for SaCas9 and 5'-NNGGAA-3' for St1Cas9 instead of 5'-NGG-3' for SpCas9) when DSBs are catalyzed at the target sites [157]. Considering that the flexibility of target sites is constrained by PAM sequences to great extent, the introduction of SaCas9 and St1Cas9 into CRIPSR group greatly expands the coverage of available target sites on plant genome and promotes CRISPR-mediated crop improvement. In addition to the mentioned type II CRISPR systems above, a CRISPR/Cpf1 platform (also named CRISPR/Cas12a) has been developed, of which several aspects are quite distinct from the Cas9 systems [158] [159]. For instance, only a crRNA is needed for guiding Cpf1-crRNA complex to target sites on plant genome, and therefore, the length of sgRNA is shortened from approximately $100 \mathrm{nt}$ in Cas9 systems to $42 \mathrm{nt}$, facilitating sgRNA synthesis. The PAM sequence of Cpf1 is 5'-TTTN-3' and the Cpf1-mediated DSBs can generate $4 \mathrm{bp}$ overhangs at $5^{\prime}$ end of cleavage sites, while blunt ends are produced after Cas9 cleavage at target sites. The resulted cohesive ends by Cpf1 display some potential advantages over blunt ends such as the improvement of knockin efficiency and the increased possibility of multiple editing events. The CRISPR/Cpf1 system is thus considered as a promising tool and has been applied in genetical modifications of crop plants [Table 8]. And we believe that this system will be widely used for crop improvement in the near future.

\section{Perspectives}

The appearance and rapid development of targeted genome engineering technologies have paved a new way for crop breeding. By now, four generations of genome editing platforms have been provided from site-specific recombination system to ZFN, TALEN and CRISPR/Cas9 technologies. CRISPR/Cas9 is now 
Table 8. The newly-developed CRISPR systems and their applications in crop improvement.

\begin{tabular}{|c|c|c|c|c|c|}
\hline System & Source & Crop & Target & Purpose & Reference \\
\hline CRISPR/FnCas9 & Francisella novicida & Tobacco & CMV and TMV genomes & Virus resistance & [160] \\
\hline CRISPR/SaCas9 & Staphylococcus aureus & Rice & $D L$ & Mutagenesis assessment & [156] \\
\hline CRISPR/SaCas9 & Staphylococcus aureus & Tobacco & PDS, FT4 & Mutagenesis assessment & [156] \\
\hline CRISPR/LshCas13a & Leptotrichia shahii & Rice & SRBSDV genome & Virus resistance & [161] \\
\hline CRISPR/LshCas13a & Leptotrichia shahii & Tobacco & TMV genome & Virus resistance & [161] \\
\hline CRISPR/Cpf1 & $\begin{array}{c}\text { Acidaminococcus sp. } \\
\text { BV3L6 }\end{array}$ & Rice & ROC5, DEP1 & $\begin{array}{l}\text { Temperature-dependent target } \\
\text { efficiency improvement }\end{array}$ & {$[162]$} \\
\hline CRISPR/Cpf1 & Francisella novicida & Rice & $D L, A L S$ & Leaf morphology & [163] \\
\hline CRISPR/Cpf1 & Francisella novicida & Tobacco & $P D S, S T F 1$ & $\begin{array}{l}\text { Leaf morphology and pigment } \\
\text { biosynthesis }\end{array}$ & [163] \\
\hline CRISPR/Cpf1 & Lachnospiraceae bacterium & Maize & $G L 2$ & Target specificity assessment & [164] \\
\hline CRISPR/Cpf1 & Lachnospiraceae bacterium & Maize & GL2 & $\begin{array}{l}\text { Temperature-dependent target } \\
\text { efficiency improvement }\end{array}$ & [162] \\
\hline CRISPR/Cpf1 & Lachnospiraceae bacterium & Rice & $\begin{array}{l}\text { DEP1, SPL14, TB1, LAC, } \\
\text { MIR398a, Os02cir25329, } \\
\text { Os03cirO0204, PDS, ROC5 }\end{array}$ & Target specificity assessment & [165] \\
\hline CRISPR/Cpf1 & Lachnospiraceae bacterium & Rice & $\begin{array}{c}B E L-230, B E L-240, B E L-250 \\
B E L-260, E P S P S, R L K-798 \\
R L K-799, R L K-802, R L K-803\end{array}$ & $\begin{array}{l}\text { Multigene mutagenesis as- } \\
\text { sessment }\end{array}$ & {$[166]$} \\
\hline CRISPR/Cpf1 & Lachnospiraceae bacterium & Rice & EPFL9 & Stomata development & {$[167]$} \\
\hline
\end{tabular}

considered as the advantageous tool over the other three and has been used in genetical modifications of crops most widely. A lot of new crop germplasms that do not exist in nature have been efficiently created via CRISPR-mediated knockout, knockin, transcriptional activation and transcriptional repression of genes of interest.

However, challenges still remain in current CRISPR platform. Thus far, most of reported modifications for crops are CRISPR-mediated gene knockouts while knockin events are rare and usually at low efficiency, though knockin is very useful for crop breeding because it can confer novel traits that do not exist in crops in nature by editing of existing alleles or adding of new ones. CRISPR/dCas9 is considered as a promising tool for transcriptional regulation of gene expression, particularly for genes with highly methylated promoter regions [168] [169], while available data for gene modification of this kind are quite limited, constraining the improvement of CRISPR-based transcriptional regulation systems and their applications in crops. Transformation and tissue culture are crucial for CRISPR-mediated genome editing, while their efficiencies are challenged for most of crop plants. Last but not the least, off-targeting is still an intensive concern for plant scientists, though numerous studies have evidenced the precision of CRISPR-mediated genome editing in plants [170]. All of these challenges should be addressed in the future studies in order to promote the applications of CRISPR systems in crop improvement. 


\section{Acknowledgements}

This work was supported by Natural Science Foundation of Guangdong Province (2018A030310446), China Postdoctoral Science Foundation (2017M612741), Guangdong Innovation Research Team Fund (2014ZT05S078), National Natural Science Foundation of China (31600982), and Shenzhen High-Level Talents Research Fund (827/000256).

\section{Conflicts of Interest}

The authors declare no conflicts of interest regarding the publication of this paper.

\section{References}

[1] Shen, W., Ni, Y., Gao, N., Bian, B., Zheng, S., Lin, X. and Chu, H. (2016) Bacterial Community Composition Is Shaped by Soil Secondary Salinization and Acidification Brought on by High Nitrogen Fertilization Rates. Applied Soil Ecology, 108, 76-83. https://doi.org/10.1016/j.apsoil.2016.08.005

[2] Bashagaluke, J.B., Logah, V., Opoku, A., Sarkodie-Addo, J. and Quansah, C. (2018) Soil Nutrient Loss through Erosion: Impact of Different Cropping Systems and Soil Amendments in Ghana. PLoS ONE, 13, e0208250. https://doi.org/10.1371/journal.pone.0208250

[3] Monroe, J.G., Powell, T., Price, N., Mullen, J.L., Howard, A., Evans, K., Lovell, J.T. and McKay, J.K. (2018) Drought Adaptation in Arabidopsis thaliana by Extensive Genetic Loss-of-Function. Elife, 7, e41038. https://doi.org/10.7554/eLife.41038

[4] Deutsch, C.A., Tewksbury, J.J., Tigchelaar, M., Battisti, D.S., Merrill, S.C., Huey, R.B. and Naylor, R.L. (2018) Increase in Crop Losses to Insect Pests in a Warming Climate. Science, 361, 916-919. https://doi.org/10.1126/science.aat3466

[5] Poveda, K., Díaz, M.F. and Ramirez, A. (2018) Can Overcompensation Increase Crop Production? Ecology, 99, 270-280. https://doi.org/10.1002/ecy.2088

[6] Ye, X., Al-Babili, S., Klöti, A., Zhang, J., Lucca, P., Beyer, P. and Potrykus, I. (2000) Engineering the Provitamin A (Beta-Carotene) Biosynthetic Pathway into (Carotenoid-Free) Rice Endosperm. Science, 287, 303-305. https://doi.org/10.1126/science.287.5451.303

[7] Paine, J.A., Shipton, C.A., Chaggar, S., Howells, R.M., Kennedy, M.J., Vernon, G., Wright, S.Y., Hinchliffe, E., Adams, J.L., Silverstone, A.L. and Drake, R. (2005) Improving the Nutritional Value of Golden Rice through Increased Pro-Vitamin A Content. Nature Biotechnology, 23, 482-487. https://doi.org/10.1038/nbt1082

[8] Federico, M.L. and Schmidt, M.A. (2016) Modern Breeding and Biotechnological Approaches to Enhance Carotenoid Accumulation in Seeds. Sub-Cellular Biochemistry, 79, 345-358. https://doi.org/10.1007/978-3-319-39126-7_13

[9] Carzoli, A.K., Aboobucker, A.I., Sandall, L.L., Lübberstedt, T.T. and Suza, W.P. (2018) Risks and Opportunities of GM Crops: Bt Maize Example. Global Food Security, 19, 84-91. https://doi.org/10.1016/j.gfs.2018.10.004

[10] Huang, J., Hu, R., Rozelle, S. and Pray, C. (2005) Insect-Resistant GM Rice in Farmers' Fields: Assessing Productivity and Health Effects in China. Science, 308, 688690. https://doi.org/10.1126/science.1108972

[11] Wei, X.D., Zou, H.L., Chu, L.M., Liao, B., Ye, C.M. and Lan, C.Y. (2006) Field Re- 
leased Transgenic Papaya Affects Microbial Communities and Enzyme Activities in Soil. Plant and Soil, 285, 347-358. https://doi.org/10.1007/s11104-006-9020-8

[12] Smyth, S.J. (2017) Genetically Modified Crops, Regulatory Delays, and International Trade. Food and Energy Security, 6, 78-86. https://doi.org/10.1002/fes3.100

[13] Rocha-Munive, M.G., Soberón, M., Castañeda, S., Niaves, E., Scheinvar, E., Eguiarte, L.E., Mota-Sánchez, D., Rosales-Robles, E., Nava-Camberos, U., MartínezCarrillo, J.L., Blanco, C.A., Bravo, A. and Souza, V. (2018) Evaluation of the Impact of Genetically Modified Cotton after 20 Years of Cultivation in Mexico. Frontiers in Bioengineering and Biotechnology, 6, 82. https://doi.org/10.3389/fbioe.2018.00082

[14] Sun, N., Abil, Z. and Zhao, H. (2012) Recent Advances in Targeted Genome Engineering in Mammalian Systems. Biotechnology Journal, 7, 1074-1087. https://doi.org/10.1002/biot.201200038

[15] Belhaj, K., Chaparro-Garcia, A., Kamoun, S. and Nekrasov, V. (2013) Plant Genome Editing Made Easy: Targeted Mutagenesis in Model and Crop Plants Using the CRISPR/Cas System. Plant Methods, 9, 39. https://doi.org/10.1186/1746-4811-9-39

[16] Cong, L., Ran, F.A., Cox, D., Lin, S., Barretto, R., Habib, N., Hsu, P.D., Wu, X., Jiang, W., Marraffini, L.A. and Zhang, F. (2013) Multiplex Genome Engineering Using CRISPR/Cas Systems. Science, 339, 819-823. https://doi.org/10.1126/science.1231143

[17] Mali, P., Yang, L., Esvelt, K.M., Aach, J., Guell, M., DiCarlo, J.E., Norville, J.E. and Church, G.M. (2013) RNA-Guided Human Genome Engineering via Cas9. Science, 339, 823-826. https://doi.org/10.1126/science.1232033

[18] Segall, A. (2001) Site-Specific Recombination. Encyclopedia of Life Sciences. John Wiley \& Sons, Ltd., New York. https://doi.org/10.1038/npg.els.0001058

[19] Esposito, D. and Scocca, J.J. (1997) The Integrase Family of Tyrosine Recombinases: Evolution of a Conserved Active Site Domain. Nucleic Acids Research, 25, 3605 3614. https://doi.org/10.1093/nar/25.18.3605

[20] Smith, M.C.M. and Thorpe, H.M. (2002) Diversity in the Serine Recombinases. Molecular Microbiology, 44, 299-307. https://doi.org/10.1046/j.1365-2958.2002.02891.x

[21] McLellan, M.A., Rosenthal, N.A. and Pinto, A.R. (2017) Cre-loxP-Mediated Recombination: General Principles and Experimental Considerations. Current Protocols in Mouse Biology, 7, 1-12. https://doi.org/10.1002/cpmo.22

[22] Bala, A., Roy, A., Das, A., Chakraborti, D. and Das, S. (2013) Development of Selectable Marker Free, Insect Resistant, Transgenic Mustard (Brassica juncea) Plants Using Cre/lox Mediated Recombination. BMC Biotechnology, 13, 88. https://doi.org/10.1186/1472-6750-13-88

[23] Sreekala, C., Wu, L., Gu, K., Wang, D., Tian, D. and Yin, Z. (2005) Excision of a Selectable Marker in Transgenic Rice (Oryza sativa L.) Using a Chemically Regulated Cre/loxP System. Plant Cell Reports, 24, 86-94. https://doi.org/10.1007/s00299-004-0909-5

[24] Cuellar, W., Gaudin, A., Solórzano, D., Casas, A., Ñopo, L., Chudalayandi, P., Medrano, G., Kreuze, J. and Ghislain, M. (2006) Self-Excision of the Antibiotic Resistance Gene NPTIIUsing a Heat Inducible Cre/loxP System from Transgenic Potato. Plant Molecular Biology, 62, 71-82. https://doi.org/10.1007/s11103-006-9004-3

[25] Zhang, Y., Li, H., Ouyang, B., Lu, Y. and Ye, Z. (2006) Chemical-Induced Auto Excision of Selectable Markers in Elite Tomato Plants Transformed with a Gene Conferring Resistance to Lepidopteran Insects. Biotechnology Letters, 28, 1247-1253. 
https://doi.org/10.1007/s10529-006-9081-Z

[26] Yu, W., Han, F., Gao, Z., Vega, J.M. and Birchler, J.A. (2007) Construction and Behavior of Engineered Minichromosomes in Maize. Proceedings of the National Academy of Sciences of the United States of America, 104, 8924-8929. https://doi.org/10.1073/pnas.0700932104

[27] Xu, C., Cheng, Z. and Yu, W. (2011) Construction of Rice Mini-Chromosomes by Telomere-Mediated Chromosomal Truncation. Plant Journal, 70, 1070-1079. https://doi.org/10.1111/j.1365-313X.2012.04916.x

[28] Radhakrishnan, P. and Srivastava, V. (2005) Utility of the FLP-FRT Recombination System for Genetic Manipulation of Rice. Plant Cell Reports, 23, 721-726. https://doi.org/10.1007/s00299-004-0876-X

[29] Djukanovic, V., Orczyk, W., Gao, H., Sun, X., Garrett, N., Zhen, S., Gordon-Kamm, W., Barton, J. and Lyznik, L.A. (2006) Gene Conversion in Transgenic Maize Plants Expressing FLP/FRT and Cre/loxP Site-Specific Recombination Systems. Plant Biotechnology Journal, 4, 345-357. https://doi.org/10.1111/j.1467-7652.2006.00186.x

[30] Würdig, J., Flachowsky, H., Saß, A., Peil, A. and Hanke, M.V. (2015) Improving Resistance of Different Apple Cultivars Using the Rvi6 Scab Resistance Gene in a Cisgenic Approach Based on the Flp/FRT Recombinase System. Molecular Breeding, 35, 95. https://doi.org/10.1007/s11032-015-0291-8

[31] Kapusi, E., Kempe, K., Rubtsova, M., Kumlehn, J. and Gils, M. (2012) PhiC31 Integrase-Mediated Site-Specific Recombination in Barley. PLoS ONE, 7, e45353. https://doi.org/10.1371/journal.pone.0045353

[32] Éva, C., Téglás, F., Zelenyánszki, H., Tamás, C., Juhász, A., Mészáros, K. and László Tamás, L. (2018) Cold Inducible Promoter Driven Cre-Lox System Proved to Be Highly Efficient for Marker Gene Excision in Transgenic Barley. Journal of Biotechnology, 265, 15-24. https://doi.org/10.1016/j.jbiotec.2017.10.016

[33] Costa, L.D., Piazza, S., Campa, M., Flachowsky, H., Hanke, M.V. and Malnoy, M. (2016) Efficient Heat-Shock Removal of the Selectable Marker Gene in Genetically Modified Grapevine. Plant Cell, Tissue and Organ Culture, 124, 471-481. https://doi.org/10.1007/s11240-015-0907-Z

[34] Martin-Ortigosa, S., Peterson, D.J., Valenstein, J.S., Lin, V.S., Trewyn, B.G., Lyznik, L.A. and Wang, K. (2014) Mesoporous Silica Nanoparticle-Mediated Intracellular Cre Protein Delivery for Maize Genome Editing via loxP Site Excision. Plant Physiology, 164, 537-547. https://doi.org/10.1104/pp.113.233650

[35] Du, D., Jin, R., Guo, J. and Zhang, F. (2019) Construction of Marker-Free Genetically Modified Maize Using a Heat-Inducible Auto-Excision Vector. Genes, 10, E374. https://doi.org/10.3390/genes10050374

[36] Boszorádová, E., Matušíková, I., Libantová, J., Zimová, M. and Moravčíková, J. (2019) Cre-Mediated Marker Gene Removal for Production of Biosafe Commercial Oilseed Rape. Acta Physiologiae Plantarum, 41, 73. https://doi.org/10.1007/s11738-019-2865-2

[37] Peng, A., Xu, L., He, Y., Lei, T., Yao, L., Chen, S. and Zou, X. (2015) Efficient Production of Marker-Free Transgenic 'Tarocco' Blood Orange (Citrus sinensis Osbeck) with Enhanced Resistance to Citrus Canker Using a Cre/loxP Site-Recombination System. Plant Cell, Tissue and Organ Culture, 123, 1-13. https://doi.org/10.1007/s11240-015-0799-y

[38] Kopertekh, L. and Schiemann, J. (2017) Marker Removal in Transgenic Plants Using Cre Recombinase Delivered with Potato Virus X. Methods in Molecular Biology, 1642, 151-168. https://doi.org/10.1007/978-1-4939-7169-5_10 
[39] Chen, H., Luo, J., Zheng, P., Zhang, X., Zhang, C., Li, X., Wang, M., Huang, Y., Liu, X., Jan, M., Liu, Y., Hu, P. and Tu, J. (2017) Application of Cre-Lox Gene Switch to Limit the Cry Expression in Rice Green Tissues. Scientific Reports, 7, 14505. https://doi.org/10.1038/s41598-017-14679-0

[40] Woo, H.J., Qin, Y., Park, S.Y., Park, S.K., Cho, Y.G., Shin, K.S., Lim, M.H. and Cho, H.S. (2015) Development of Selectable Marker-Free Transgenic Rice Plants with Enhanced Seed Tocopherol Content through FLP/FRT-Mediated Spontaneous Auto-Excision. PLoS ONE, 10, e0132667. https://doi.org/10.1371/journal.pone.0132667

[41] Zhang, X., Dong, Q., Qiao, X., Qiao, Y., Wang, B., Zhang, K. and Li, G. (2019) Creation and Analysis of Marker Free Transgenic Soybean Germplasm with Low Phosphate Tolerance Transcription Factor GmPTFl Based on Cre/loxP System. Acta Agronomica Sinica, 45, 683-692.

http://kns.cnki.net/kcms/detail/11.1809.S.20190115.1603.004.html

[42] Zheng, Y., Pan, Y., Li, J., Zhou, Y, Pan, Y., Ding, Y., Su, C. and Zhang, X. (2016) Visible Marker Excision via Heat-Inducible Cre/LoxP System and Ipt Selection in Tobacco. In Vitro Cellular \& Developmental Biology-Plant, 52, 492-499. https://doi.org/10.1007/s11627-016-9775-4

[43] Moon, H., Abercrombie, L., Eda, S., Blanvillain, R., Thomson, J., Ow, D. and Stewart Jr., C.N. (2011) Transgene Excision in Pollen Using a Codon Optimized Serine Resolvase CinH-RS2 Site-Specific Recombination System. Plant Molecular Biology, 75, 621-631. https://doi.org/10.1007/s11103-011-9756-2

[44] Shao, M., Blechl, A. and Thomson, J.G. (2017) Small Serine Recombination Systems ParA-MRS and CinH-RS2 Perform Precise Excision of Plastid DNA. Plant Biotechnology Journal, 15, 1577-1589. https://doi.org/10.1111/pbi.12740

[45] Mészáros, K., Éva, C., Kiss, T., Bányai, J., Kiss, E., Téglás, F., Karsai, L.L. and Tamás, L. (2015) Generating Marker-Free Transgenic Wheat Using Minimal Gene Cassette and Cold-Inducible Cre/Lox System. Plant Molecular Biology Reporter, 33, 1221 1231. https://doi.org/10.1007/s11105-014-0830-1

[46] Anand, A., Wu, E., Li, Z., TeRonde, S., Arling, M., Lenderts, B., Mutti, J.S., Gordon-Kamm, W., Jones, T.J. and Chilcoat, N.D. (2019) High Efficiency Agrobacterium-Mediated Site-Specific Gene Integration in Maize Utilizing the FLP-FRT Recombination System. Plant Biotechnology Journal, 17, 1636-1645.

https://doi.org/10.1111/pbi.13089

[47] Yan, X., Li, C., Yang, J., Wang, L., Jiang, C. and Wei, W. (2017) Induction of Telomere-Mediated Chromosomal Truncation and Behavior of Truncated Chromosomes in Brassica napus. Plant Journal, 91, 700-713.

https://doi.org/10.1111/tpj.13598

[48] Chawla, R., Ariza-Nieto, M., Wilson, A.J., Moore, S.K. and Srivastava, V. (2006) Transgene Expression Produced by Biolistic-Mediated, Site-Specific Gene Integration Is Consistently Inherited by the Subsequent Generations. Plant Biotechnology Journal, 4, 209-218. https://doi.org/10.1111/j.1467-7652.2005.00173.x

[49] Srivastava, V. (2019) Gene Stacking in Plants through the Application of Site-Specific Recombination and Nuclease Activity. Methods in Molecular Biology, 1864, 267-277. https://doi.org/10.1007/978-1-4939-8778-8_18

[50] Li, Z., Xing, A., Moon, B.P., McCardell, R.P., Mills, K. and Falco, S.C. (2009) Site-Specific Integration of Transgenes in Soybean via Recombinase-Mediated DNA Cassette Exchange. Plant Physiology, 151, 1087-1095.

https://doi.org/10.1104/pp.109.137612 
[51] Ebinuma, H., Nakahama, K. and Nanto, K. (2015) Enrichments of Gene Replacement Events by Agrobacterium-Mediated Recombinase-Mediated Cassette Exchange. Molecular Breeding, 35, 82. https://doi.org/10.1007/s11032-015-0215-7

[52] Vibha Srivastava, V. and Gidoni, D. (2010) Site-Specific Gene Integration Technologies for Crop Improvement. In Vitro Cellular \& Developmental Biology-Plant, 46, 219-232. https://doi.org/10.1007/s11627-009-9274-y

[53] Beerli, R.R. and Barbas, C.F. (2002) Engineering Polydactyl Zinc-Finger Transcription Factors. Nature Biotechnology, 20, 135-141. https://doi.org/10.1038/nbt0202-135

[54] Perez, E.E., Wang, J., Miller, J.C., Jouvenot, Y., Kim, K.A., Liu, O., Wang, N., Lee, G., Bartsevich, V.V., Lee, Y.L., Guschin, D.Y., Rupniewski, I., Waite, A.J., Carpenito, C., Carroll, R.G., Orange, J.S., Urnov, F.D., Rebar, E.J., Ando, D., Gregory, P.D., Riley, J.L., Holmes, M.C. and June, C.H. (2008) Establishment of HIV-1 Resistance in $\mathrm{CD}^{4+} \mathrm{T}$ Cells by Genome Editing Using Zinc-Finger Nucleases. Nature Biotechnology, 26, 808-816. https://doi.org/10.1038/nbt1410

[55] Holt, N., Wang, J., Kim, K., Friedman, G., Wang, X., Taupin, V., Crooks, G.M., Kohn, D.B., Gregory, P.D., Holmes, M.C. and Cannon, P.M. (2010) Human Hematopoietic Stem/Progenitor Cells Modified by Zinc-Finger Nucleases Targeted to CCR5 Control HIV-1 in Vivo. Nature Biotechnology, 28, 839-847.

https://doi.org/10.1038/nbt.1663

[56] Shukla, V.K., Doyon, Y., Miller, J.C., DeKelver, R.C., Moehle, E.A., Worde, S.E., Mitchell, J.C., Arnold, N.L., Gopalan, S., Meng, X., Choi, V.M., Rock, J.M., Wu, Y.Y., Katibah, G.E., Gao, Z., McCaskill, D., Simpson, M.A., Blakeslee, B., Greenwalt, S.A., Butler, H.J., Hinkley, S.J., Zhang, L., Rebar, E.J., Gregory, P.D. and Urnov, F.D. (2009) Precise Genome Modification in the Crop Species Zea mays Using ZincFinger Nucleases. Nature, 459, 437-441. https://doi.org/10.1038/nature07992

[57] Li, H., Haurigot, V., Doyon, Y., Li, T., Wong, S.Y., Bhagwat, A.S., Malani, N., Anguela, X.M., Sharma, R., Ivanciu, L., Murphy, S.L., Finn, J.D., Khazi, F.R., Zhou, S., Paschon, D.E., Rebar, E.J., Bushman, F.D., Gregory, P.D., Holmes, M.C. and High, K.A. (2011) In Vivo Genome Editing Restores Homostasis in a Mouse Model of Haemophilia. Nature, 475, 217-221. https://doi.org/10.1038/nature10177

[58] Zou, J., Mali, P., Huang, X., Dowey, S.N. and Cheng, L. (2011) Site-Specific Gene Correction of a Point Mutation in Human iPS Cells Derived from an Adult Patient with Sickle Cell Disease. Blood, 118, 4599-4608. https://doi.org/10.1182/blood-2011-02-335554

[59] Soldner, F., Laganière, J., Cheng, A.W., Hockemeyer, D., Gao, Q., Alagappan, R., Khurana, V., Golbe, L.I., Myers, R.H., Lindquist, S., Zhang, L., Guschin, D., Fong, L.K., Vu, B.J., Meng, X., Urnov, F.D., Gregory, P.D., Zhang, H.S. and Jaenisch, R. (2011) Generation of Isogenic Pluripotent Stem Cells Differing Exclusively at Two Early Onset Parkinson Point Mutations. Cell, 146, 659.

https://doi.org/10.1016/j.cell.2011.06.019

[60] Cai, C.Q., Doyon, Y., Ainley, W.M., Miller, J.C., DeKelver, R.C., Moehle, E.A., Rock, J.M., Lee, Y., Garrison, R., Schulenberg, L., Blue, R., Worden, A., Baker, L., Faraji, F., Zhang, L., Holmes, M.C., Rebar, E.J., Collingwood, T.N., Rubin-Wilson, B., Gregory, P.D., Urnov, F.D. and Petolino, J.F. (2009) Targeted Transgene Integration in Plant Cells Using Designed Zinc Finger Nucleases. Plant Molecular Biology, 69, 699-709. https://doi.org/10.1007/s11103-008-9449-7

[61] Kelly, K.F. and Daniel, J.M. (2006) POZ for Effect-POZ-ZF Transcription Factors in Cancer and Development. Trends in Cell Biology, 16, 578-587.

https://doi.org/10.1016/j.tcb.2006.09.003 
[62] Peer, R., Rivlin, G., Golobovitch, S., Lapidot, M., Gal-On, A., Vainstein, A., Tzfira, T. and Flaishman, M.A. (2015) Targeted Mutagenesis Using Zinc-Finger Nucleases in Perennial Fruit Trees. Planta, 241, 941-951. https://doi.org/10.1007/s00425-014-2224-x

[63] Lu, H.W., Klocko, A.L., Dow, M., Ma, C., Amarasinghe, V. and Strauss, S.H. (2016) Low Frequency of Zinc-Finger Nuclease-Induced Mutagenesis in Populus. Molecular Breeding, 36, 121. https://doi.org/10.1007/s11032-016-0546-Z

[64] Townsend, J.A., Wright, D.A., Winfrey, R.J., Fu, F., Maeder, M.L., Joung, J.K. and Voytas, D.F. (2009) High-Frequency Modification of Plant Genes Using Engineered Zinc-Finger Nucleases. Nature, 459, 442-445. https://doi.org/10.1038/nature07845

[65] Petolino, J.F., Worden, A., Curlee, K., Connell, J., Strange Moynahan, T.L., Larsen, C. and Russell, S. (2010) Zinc Finger Nuclease-Mediated Transgene Deletion. Plant Molecular Biology, 73, 617-628. https://doi.org/10.1007/s11103-010-9641-4

[66] Curtin, S.J., Zhang, F., Sander, J.D., Haun, W.J., Starker, C., Baltes, N.J., Reyon, D., Dahlborg, E.J., Goodwin, M.J., Coffman AP, Dobbs, D., Joung, J.K., Voytas, D.F. and Stupar, R.M. (2011) Targeted Mutagenesis of Duplicated Genes in Soybean with Zinc-Finger Nucleases. Plant Physiology, 156, 466-473. https://doi.org/10.1104/pp.111.172981

[67] Ainley, W.M., Sastry-Dent, L., Welter, M.E., Murray, M.G., Zeitler, B., Amora, R., Corbin, D.R., Miles, R.R., Arnold, N.L., Strange, T.L., Simpson, M.A., Cao, Z., Carroll, C., Pawelczak, K.S., Blue, R., West, K., Rowland, L.M., Perkins, D., Samuel, P., Dewes, C.M., Shen, L., Sriram, S., Evans, S.L., Rebar, E.J., Zhang, L., Gregory, P.D., Urnov, F.D., Webb, S.R. and Petolino, J.F. (2013) Trait Stacking via Targeted Genome Editing. Plant Biotechnology Journal, 11, 1126-1134.

https://doi.org/10.1111/pbi.12107

[68] Kumar, S., AlAbed. D., Worden, A., Novak, S., Wu, H., Ausmus, C., Beck, M., Robinson, H., Minnicks, T., Hemingway, D., Lee, R., Skaggs, N., Wang, L., Marri, P. and Gupta, M. (2015) A Modular Gene Targeting System for Sequential Transgene Stacking in Plants. Journal of Biotechnology, 207, 12-20. https://doi.org/10.1016/j.jbiotec.2015.04.006

[69] Kumar, S., Worden, A., Novak, S., Lee, R. and Petolino, J.F. (2016) A Trait Stacking System via Intragenomic Homologous Recombination. Planta, 244, 1157-1166.

https://doi.org/10.1007/s00425-016-2595-2

[70] Cantos, C., Francisco, P., Trijatmiko, K.R., Slamet-Loedin, I. and Chadha-Mohanty, P.K. (2014) Identification of "Safe Harbor" Loci in Indica Rice Genome by Harnessing the Property of Zinc Finger Nucleases to Induce DNA Damage and Repair. Frontiers in Plant Science, 5, 302. https://doi.org/10.3389/fpls.2014.00302

[71] Bonawitz, N.D., Ainley, W.M., Itaya, A., Chennareddy, S.R., Cicak, T., Effinger, K., Jiang, K., Mall, T.K., Marri, P.R., Samuel, J.P., Sardesai, N., Simpson, M., Folkerts, O., Sarria, R., Webb, S.R., Gonzalez, D.O., Simmonds, D.H. and Pareddy, D.R. (2019) Zinc Finger Nuclease-Mediated Targeting of Multiple Transgenes to an Endogenous Soybean Genomic Locus via Non-Homologous End Joining. Plant Biotechnology Journal, 17, 750-761. https://doi.org/10.1111/pbi.13012

[72] Schneider, K., Schiermeyer, A., Dolls, A., Koch, N., Herwartz, D., Kirchhoff, J., Fischer, R., Russell, S.M., Cao, Z.H., Corbin, D.R., Sastry-Dent, L., Ainley, W.M., Webb, S.R., Schinkel, H. and Schillberg, S. (2016) Targeted Gene Exchange in Plant Cells Mediated by a Zinc Finger Nuclease Double Cut. Plant Biotechnology Journal, 14, 1151-1160. https://doi.org/10.1111/pbi.12483

[73] Gupta, M., DeKelver, R.C., Palta, A., Clifford, C., Gopalan, S., Miller, J.C., Novak, 
S., Desloover, D., Gachotte, D., Connell, J., Flook, J., Patterson, T., Robbins, K., Rebar, E.J., Gregory, P.D., Urnov, F.D. and Petolino, J.F. (2012) Transcriptional Activation of Brassica napus Beta-Ketoacyl-ACP Synthase II with an Engineered Zinc Finger Protein Transcription Factor. Plant Biotechnology Journal, 10, 783-791. https://doi.org/10.1111/j.1467-7652.2012.00695.x

[74] Rinaldo, A.R. and Ayliffe, M. (2015) Gene Targeting and Editing in Crop Plants: A New Era of Precision Opportunities. Molecular Breeding, 35, 40. https://doi.org/10.1007/s11032-015-0210-Z

[75] Gaj, T., Gersbach, C.A. and Barbas, C.F. (2013) ZFN, TALEN and CRISPR/CasBased Methods for Genome Engineering. Trends in Biotechnology, 31, 397-405. https://doi.org/10.1016/j.tibtech.2013.04.004

[76] Li, T., Liu, B., Spalding, M.H., Weeks, D.P. and Yang, B. (2012) High-Efficiency TALEN-Based Gene Editing Produces Disease-Resistant Rice. Nature Biotechnology, 30, 390-392. https://doi.org/10.1038/nbt.2199

[77] Shan, Q., Zhang, Y., Chen, K., Zhang, K. and Gao, C. (2015) Creation of Fragrant Rice by Targeted Knockout of the OsBADH2 Gene Using TALEN Technology. Plant Biotechnology Journal, 13, 791-800. https://doi.org/10.1111/pbi.12312

[78] Gao, X., Tsang, J.C., Gaba, F., Wu, D., Lu, L. and Liu, P. (2014) Comparison of TALE Designer Transcription Factors and the CRISPR/dCas9 in Regulation of Gene Expression by Targeting Enhancers. Nucleic Acids Research, 42, e155. https://doi.org/10.1093/nar/gku836

[79] Sun, Z., Li, N., Huang, G., Xu, J., Pan, Y., Wang, Z., Tang, Q., Song, M. and Wang, X. (2013) Site-Specific Gene Targeting Using Transcription Activator-Like Effector (TALE)-Based Nuclease in Brassica oleracea. Journal of Integrative Plant Biology, 55, 1092-1103. https://doi.org/10.1111/jipb.12091

[80] Char, S.N., Unger-Wallace, E., Frame, B., Briggs, S.A., Main, M., Spalding, M.H., Spalding, M.H., Vollbrecht, E., Wang, K. and Yang, B. (2015) Heritable Site-Specific Mutagenesis Using TALENs in Maize. Plant Biotechnology Journal, 13, 1002-1010. https://doi.org/10.1111/pbi.12344

[81] Kelliher, T., Starr, D., Richbourg, L., Chintamanani, S., Delzer, B., Nuccio, M.L., Green, J., Chen, Z., McCuiston, J., Wang, W., Liebler, T., Bullock, P. and Martin, B. (2017) MATRILINEAL, a Sperm-Specific Phospholipase, Triggers Maize Haploid Induction. Nature, 542, 105-109. https://doi.org/10.1038/nature20827

[82] Wen, S., Liu, H., Li, X., Chen, X., Hong, Y., Li, H., Lu, Q. and Liang, X. (2018) TALEN-Mediated Targeted Mutagenesis of Fatty Acid Desaturase 2 (FAD2) in Peanut (Arachis hypogaea L.) Promotes the Accumulation of Oleic Acid. Plant Molecular Biology, 97, 177-185. https://doi.org/10.1007/s11103-018-0731-z

[83] Sawai, S., Ohyama, K., Yasumoto, S., Seki, H., Sakuma, T., Yamamoto, T., Takebayashi, Y., Kojima, M., Sakakibara, H., Aoki, T., Muranaka, T., Saito, K. and Umemoto, N. (2014). Sterol Side Chain Reductase 2 Is a Key Enzyme in the Biosynthesis of Cholesterol, the Common Precursor of Toxic Steroidal Glycoalkaloids in Potato. Plant Cell, 26, 3763-3774. https://doi.org/10.1105/tpc.114.130096

[84] Nicolia, A., Proux-Wéra, E., Åhman, I., Onkokesung, N., Andersson, M., Andreasson, E. and Zhu, L.H. (2015) Targeted Gene Mutation in Tetraploid Potato through Transient TALEN Expression in Protoplasts. Journal of Biotechnology, 204, 17-24. https://doi.org/10.1016/j.jbiotec.2015.03.021

[85] Clasen, B.M., Stoddard, T.J., Luo, S., Demorest, Z.L., Li, J., Cedrone, F., Tibebu, R., Davison, S., Ray, E.E., Daulhac, A., Coffman, A., Yabandith, A., Retterath, A., Haun, W., Baltes, N.J., Mathis, L., Voytas, D.F. and Zhang, F. (2016) Improving Cold Sto- 
rage and Processing Traits in Potato through Targeted Gene Knockout. Plant Biotechnology Journal, 14, 169-176. https://doi.org/10.1111/pbi.12370

[86] Ma, J., Xiang, H., Donnelly, D.J., Meng, F.R., Xu, H., Durnford, D. and Li, X. (2017) Genome Editing in Potato Plants by Agrobacterium-Mediated Transient Expression of Transcription Activator-Like Effector Nucleases. Plant Biotechnology Reports, 11, 249-258. https://doi.org/10.1007/s11816-017-0448-5

[87] Blanvillain-Baufume, S., Reschke, M., Sole, M., Auguy, F., Doucoure, H., Szurek, B., Meynard, D., Portefaix, M., Cunnac, S., Guiderdoni, E., Boch, J. and Koebnik, R. (2017) Targeted Promoter Editing for Rice Resistance to Xanthomonas oryzae pv. oryzae Reveals Differential Activities for SWEET14-Inducing TAL Effectors. Plant Biotechnology Journal, 15, 306-317. https://doi.org/10.1111/pbi.12613

[88] Jung, J.H. and Altpeter, F. (2016) TALEN Mediated Targeted Mutagenesis of Thecaffeic Acid O-Methyltransferase in Highly Polyploid Sugarcane Improves Cell Wall Composition for Production of Bioethanol. Plant Molecular Biology, 92, 131-142. https://doi.org/10.1007/s11103-016-0499-y

[89] Kannan, B., Jung, J.H., Moxley, G.W., Lee, S.M. and Altpeter, F. (2018) TALENMediated Targeted Mutagenesis of more than 100 COMT Copies/Alleles in Highly Polyploid Sugarcane Improves Saccharification Efficiency without Compromising Biomass Yield. Plant Biotechnology Journal, 16, 856-866.

https://doi.org/10.1111/pbi.12833

[90] Haun, W., Coffman, A., Clasen, B.M., Demorest, Z.L., Lowy, A., Ray, E., Retterath, A., Stoddard, T., Juillerat, A., Cedrone, F., Mathis, L., Voytas, D.F. and Zhang, F. (2014) Improved Soybean Oil Quality by Targeted Mutagenesis of the Fatty Acid Desaturase 2 Gene Family. Plant Biotechnology Journal, 12, 934-940. https://doi.org/10.1111/pbi.12201

[91] Demorest, Z.L., Coffman, A., Baltes, N.J., Stoddard, T.J., Clasen, B.M., Luo, S., Retterath, A., Yabandith, A., Gamo, M.E., Bissen, J., Mathis, L., Voytas, D.F. and Zhang, F. (2016) Direct Stacking of Sequence-Specific Nuclease-Induced Mutations to Produce High Oleic and Low Linolenic Soybean Oil. BMC Plant Biology, 16, 225. https://doi.org/10.1186/s12870-016-0906-1

[92] Zhang, Y., Zhang, F., Li, X., Baller, J.A., Qi, Y., Starker, C.G., Bogdanove, A.J. and Voytas, D.F. (2013) Transcription Activator-Like Effector Nucleases Enable Efficient Plant Genome Engineering. Plant Physiology, 161, 20-27.

https://doi.org/10.1104/pp.112.205179

[93] Wang, Y., Cheng, X., Shan, Q., Zhang, Y., Liu, J., Gao, C. and Qiu, J.L. (2014) Simultaneous Editing of Three Homoeoalleles in Hexaploid Bread Wheat Confers Heritable Resistance to Powdery Mildew. Nature Biotechnology, 32, 947-951. https://doi.org/10.1038/nbt.2969

[94] Budhagatapalli, N., Rutten, T., Gurushidze, M., Kumlehn, J. and Hensel, G. (2015) Targeted Modification of Gene Function Exploiting Homology-Directed Repair of TALEN-Mediated Double-Strand Breaks in Barley. G3-Genes Genomes Genetics, 5, 1857-1863. https://doi.org/10.1534/g3.115.018762

[95] Butler, N.M., Baltes, N.J., Voytas, D.F. and Douches, D.S. (2016) Geminivirus-Mediated Genome Editing in Potato (Solanum tuberosum L.) Using SequenceSpecific Nucleases. Frontiers in Plant Science, 7, 1045. https://doi.org/10.3389/fpls.2016.01045

[96] Forsyth, A., Weeks, T., Richael, C. and Duan, H. (2016) Transcription Activator-Like Effector Nucleases (TALEN)-Mediated Targeted DNA Insertion in Potato Plants. Frontiers in Plant Science, 7, 1572. https://doi.org/10.3389/fpls.2016.01572 
[97] Li, T., Liu, B., Chen, C.Y. and Yang, B. (2016) TALEN-Mediated Homologous Recombination Produces Site-Directed DNA Base Change and Herbicide-Resistant Rice. Journal of Genetics and Genomics, 43, 297-305. https://doi.org/10.1016/j.jgg.2016.03.005

[98] Čermák, T., Baltes, N.J., Čegan, R., Zhang, Y. and Voytas, D.F. (2015) High-Frequency, Precise Modification of the Tomato Genome. Genome Biology, 16, 232. https://doi.org/10.1186/s13059-015-0796-9

[99] Terns, M.P. and Terns, R.M. (2011) CRISPR-Based Adaptive Immune Systems. Current Opinion in Microbiology, 14, 321-327. https://doi.org/10.1016/j.mib.2011.03.005

[100] Marraffini, L.A. and Sontheimer, E.J. (2008) CRISPR Interference Limits Horizontal Gene Transfer in Staphylococci by Targeting DNA. Science, 322, 1843-1845. https://doi.org/10.1126/science.1165771

[101] Gasiunas, G., Barrangou, R., Horvath, P. and Siksnys, V. (2012) Cas9-crRNA Ribonucleoprotein Complex Mediates Specific DNA Cleavage for Adaptive Immunity in Bacteria. Proceedings of the National Academy of Sciences of the United States of America, 109, E2579-E2586. https://doi.org/10.1073/pnas.1208507109

[102] Wiedenheft, B., van Duijn, E., Bultema, J.B., Waghmare, S.P., Zhou, K., Barendregt, A., Westphal, W., Heck, A.J.R., Boekema, E.J., Dickman, M.J. and Doudna. J.A. (2011) RNA-Guided Complex from a Bacterial Immune System Enhances Target Recognition through Seed Sequence Interactions. Proceedings of the National Academy of Sciences of the United States of America, 108, 10092-10097. https://doi.org/10.1073/pnas.1102716108

[103] Wang, H., Yang, H., Shivalila, C.S., Dawlaty, M.M., Cheng, A.W., Zhang, F. and Jaenisch, R. (2013) One-Step Generation of Mice Carrying Mutations in Multiple Genes by CRISPR/Cas-Mediated Genome Engineering. Cell, 153, 910-918. https://doi.org/10.1016/j.cell.2013.04.025

[104] Shalem, O., Sanjana, N.E., Hartenian, E., Shi, X., Scott, D.A., Mikkelson, T., Heckl, D., Ebert, B.L., Root, D.E., Doench, J.G. and Zhang, F. (2014) Genome-Scale CRISPRCas9 Knockout Screening in Human Cells. Science, 343, 84-87. https://doi.org/10.1126/science.1247005

[105] Jiang, W., Zhou, H., Bi, H., Fromm, M., Yang, B. and Weeks, D.P. (2013) Demonstration of CRISPR/Cas9/sgRNA-Mediated Targeted Gene Modification in Arabidopsis, Tobacco, Sorghum and Rice. Nucleic Acids Research, 41, e188. https://doi.org/10.1093/nar/gkt780

[106] Shan, Q., Wang, Y., Li, J., Zhang, Y., Chen, K., Liang, Z., Zhang, K., Liu, J., Xi, J., Qiu, J. and Gao, C. (2013) Targeted Genome Modification of Crop Plants Using a CRISPR-Cas System. Nature Biotechnology, 31, 686-688.

https://doi.org/10.1038/nbt.2650

[107] Ran, F.A., Hsu, P.D., Lin, C.Y., Gootenberg, J.S., Konermann, S., Trevino, A.E., Scott, D.A., Inoue, A., Matoba, S., Zhang. Y. and Zhang, F. (2013) Double Nicking by RNA-Guided CRISPR Cas9 for Enhanced Genome Editing Specificity. Cell, 154, 1380-1389. https://doi.org/10.1016/j.cell.2013.08.021

[108] Gilbert, L.A., Larson, M.H., Morsut, L., Liu, Z., Brar, G.A., Torres, S.E., Stern-Ginossar, N., Brandman, O., Whitehead, E.H., Doudna, J.A., Lim ,W.A., Weissman, J.S. and Qi, L.S. (2013) CRISPR-Mediated Modular RNA-Guided Regulation of Transcription in Eukaryotes. Cell, 154, 442-451.

https://doi.org/10.1016/j.cell.2013.06.044 
[109] Kumlehn, J., Pietralla, J., Hensel, G., Pacher, M. and Puchta, H. (2018) The CRISPR/Cas Revolution Continues: From Efficient Gene Editing for Crop Breeding to Plant Synthetic Biology. Journal of Integrative Plant Biology, 60, 1127-1153. https://doi.org/10.1111/jipb.12734

[110] Shimatani, Z., Kashojiya, S., Takayama, M., Terada, R., Arazoe, T., Ishii, H., Teramura, H., Yamamoto, T., Komatsu, H., Miura, K., Ezura, H., Nishida, K., Ariizumi, T. and Kondo, A. (2017) Targeted Base Editing in Rice and Tomato Using a CRISPRCas9 Cytidine Deaminase Fusion. Nature Biotechnology, 35, 441-443.

https://doi.org/10.1038/nbt.3833

[111] Zong, Y., Wang, Y., Li, C., Zhang, R., Chen, K., Ran, Y., Qiu, J.L., Wang, D. and Gao, C. (2017) Precise Base Editing in Rice, Wheat and Maize with a Cas9-Cytidine Deaminase Fusion. Nature Biotechnology, 35, 438-440.

https://doi.org/10.1038/nbt.3811

[112] Endo, M., Mikami, M., Endo, A., Kaya, H., Itoh, T., Nishimasu, H., Nureki, O. and Toki, S. (2018) Genome Editing in Plants by Engineered CRISPR-Cas9 Recognizing NG PAM. Nature Plants, 5, 14-17. https://doi.org/10.1038/s41477-018-0321-8

[113] Hua, K., Tao, X., Yuan, F., Wang, D. and Zhu, J.K. (2018) Precise A.T to G.C Base Editing in the Rice Genome. Molecular Plant, 11, 627-630. https://doi.org/10.1016/j.molp.2018.02.007

[114] Kang, B.C., Yun, J.Y., Kim, S.T., Shin, Y., Ryu, J., Choi, M., Woo, J.W. and Kim, J.S. (2018) Precision Genome Engineering through Adenine Base Editing in Plants. Nature Plants, 4, 427-431. https://doi.org/10.1038/s41477-018-0115-Z

[115] Li, C., Zong, Y., Wang, Y., Jin, S., Zhang, D., Song, Q., Zhang, R. and Gao, C. (2018) Expanded Base Editing in Rice and Wheat Using a Cas9-Adenosine Deaminase Fusion. Genome Biology, 19, 59. https://doi.org/10.1186/s13059-018-1443-Z

[116] Tian, S., Jiang, L., Cui, X., Zhang, J., Guo, S., Li, M., Zhang, H., Ren, Y., Gong, G., Zong, M., Liu, F., Chen, Q. and Xu, Y. (2018) Engineering Herbicide-Resistant Watermelon Variety through CRISPR/Cas9-Mediated Base-Editing. Plant Cell Reports, 37, 1353-1356. https://doi.org/10.1007/s00299-018-2299-0

[117] Yan, F., Kuang, Y., Ren, B., Wang, J., Zhang, D., Lin, H., Yang, B., Zhou, X. and Zhou, H. (2018) Highly Efficient A.T to G.C Base Editing by Cas9n-Guided tRNA Adenosine Deaminase in Rice. Molecular Plant, 11, 631-634.

https://doi.org/10.1016/j.molp.2018.02.008

[118] Zong, Y., Song, Q., Li, C., Jin, S., Zhang, D., Wang, Y., Qiu, J. and Gao, C. (2018) Efficient C-to-T Base Editing in Plants Using a Fusion of nCas9 and Human APOBEC $3 A$. Nature Biotechnology, 36, 950-953. https://doi.org/10.1038/nbt.4261

[119] Malnoy, M., Viola, R., Jung, M.H., Koo, O.J., Kim, S., Kim, J.S., Velasco, R. and Kanchiswamy, C.N. (2016) DNA-Free Genetically Edited Grapevine and Apple Protoplast Using CRISPR/Cas9 Ribonucleoproteins. Frontiers in Plant Science, 7, 1904. https://doi.org/10.3389/fpls.2016.01904

[120] Nishitani, C., Hirai, N., Komori, S., Wada, M., Okada, K., Osakabe, K., Yamamoto, T. and Osakabe, Y. (2016) Efficient Genome Editing in Apple Using a CRISPR/Cas9 system. Scientific Reports, 6, 31481. https://doi.org/10.1038/srep31481

[121] Kaur, N., Alok, A., Shivani, Kaur, N., Pandey, P., Awasthi, P. and Tiwari, S. (2018) CRISPR/Cas9-Mediated Efficient Editing in Phytoene Desaturase (Pds) Demonstrates Precise Manipulation in Banana cv. Rasthali Genome. Functional \& Integrative Genomics, 18, 89-99. https://doi.org/10.1007/s10142-017-0577-5

[122] Morineau, C., Bellec, Y., Tellier, F., Gissot, L., Kelemen, Z., Nogue, F. and Faure, 
J.D. (2017) Selective Gene Dosage by CRISPR-Cas9 Genome Editing in Hexaploid Camelina sativa. Plant Biotechnology Journal, 15, 729-739. https://doi.org/10.1111/pbi.12671

[123] Odipio, J., Alicai, T., Ingelbrecht, I., Nusinow, D.A., Bart, R. and Taylor, N.J. (2017) Efficient CRISPR/Cas9 Genome Editing of Phytoene Desaturase in Cassava. Frontiers in Plant Science, 8, 1780. https://doi.org/10.3389/fpls.2017.01780

[124] Gomez, M.A., Lin, Z.D., Moll, T., Chauhan, R.D., Hayden, L., Renninger, K., Beyene, G., Taylor, N.J., Carrington, J.C., Staskawicz, B.J. and Bart, R.S. (2019) Simultaneous CRISPR/Cas9-Mediated Editing of Cassava eIF4E Isoforms nCBP-1 and $n C B P-2$ Reduces Cassava Brown Streak Disease Symptom Severity and Incidence. Plant Biotechnology Journal, 17, 421-434. https://doi.org/10.1111/pbi.12987

[125] Peng, A., Chen, S., Lei, T., Xu, L., He, Y., Wu, L., Yao, L. and Zou, X. (2017) Engineering Canker-Resistant Plants through CRISPR/Cas9-Targeted Editing of the Susceptibility Gene CsLOB1 Promoter in Citrus. Plant Biotechnology Journal, 15, 1509-1519. https://doi.org/10.1111/pbi.12733

[126] Chandrasekaran, J., Brumin, M., Wolf, D., Leibman, D., Klap, C., Pearlsman, M., Sherman, A., Arazi, T. and Gal-On, A. (2016) Development of Broad Virus Resistance in Non-Transgenic Cucumber Using CRISPR/Cas9 Technology. Molecular Plant Pathology, 17, 1140-1153. https://doi.org/10.1111/mpp.12375

[127] Ren, C., Liu, X., Zhang, Z., Wang, Y., Duan, W., Li, S. and Liang, Z. (2016) CRISPR/Cas9-Mediated Efficient Targeted Mutagenesis in Chardonnay (Vitis vinifera L.). Scientific Reports, 6, 32289. https://doi.org/10.1038/srep32289

[128] Okuzaki, A., Ogawa, T., Koizuka, C., Kaneko, K., Inaba, M., Imamura, J. and Koizuka, N. (2018) CRISPR/Cas9-Mediated Genome Editing of the Fatty Acid Desaturase 2 Gene in Brassica napus. Plant Physiology and Biochemistry, 131, 63-69. https://doi.org/10.1016/j.plaphy.2018.04.025

[129] Sauer, N.J., Narvaez-Vasquez, J., Mozoruk, J., Miller, R.B., Warburg, Z.J., Woodward, M.J., Mihiret, Y.A., Lincoln, T.A., Segami, R.E., Sanders, S.L., Walker, K.A., Beetham, P.R., Schöpke, C.R. and Gocal, G.F. (2016) Oligonucleotide-Mediated Genome Editing Provides Precision and Function to Engineered Nucleases and Antibiotics in Plants. Plant Physiology, 170, 1917-1928.

https://doi.org/10.1104/pp.15.01696

[130] Andersson, M., Turesson, H., Nicolia, A., Fält, A.S., Samuelsson, M. and Hofvander, P. (2017) Efficient Targeted Multiallelic Mutagenesis in Tetraploid Potato (Solanum tuberosum) by Transient CRISPR-Cas9 Expression in Protoplasts. Plant Cell Reports, 36, 117-128. https://doi.org/10.1007/s00299-016-2062-3

[131] Zhou, X., Zha, M., Huang, J., Li, L., Imran, M. and Zhang, C. (2017) StMYB44 Negatively Regulates Phosphate Transport by Suppressing Expression of PHOSPHATE1 in Potato. Journal of Experimental Botany, 68, 1265-1281. https://doi.org/10.1093/jxb/erx026

[132] Ye, M., Peng, Z., Tang, D., Yang, Z., Li, D., Xu, Y., Zhang, C. and Huang, S. (2018) Generation of Self-Compatible Diploid Potato by Knockout of $S$-RNase. Nature Plants, 4, 651-654. https://doi.org/10.1038/s41477-018-0218-6

[133] Wang, F., Wang, C., Liu, P., Lei, C., Hao, W., Gao, Y., Liu, Y.G. and Zhao, K. (2016) Enhanced Rice Blast Resistance by CRISPR/Cas9-Targeted Mutagenesis of the ERF Transcription Factor Gene OSERF922. PLoS ONE, 11, 0154027. https://doi.org/10.1371/journal.pone.0154027

[134] Cordones, M.N., Mohamed, S., Tanoi, K., Natsuko Kobayashi, N.I., Takagi, K., 
Vernet, A., Guiderdoni, E., Périn, C., Sentenac, H. and Véry, A.A. (2017) Production of Low-Cs ${ }^{+}$Rice Plants by Inactivation of the $\mathrm{K}^{+}$Transporter OsHAK1 with the CRISPR-Cas System. Plant Journal, 92, 43-56. https://doi.org/10.1111/tpj.13632

[135] Yang, X., Chen, L., He, J. and Yu, W. (2017) Knocking out of Carotenoid Catabolic Genes in Rice Fails to Boost Carotenoid Accumulation, But Reveals a Mutation in Strigolactone Biosynthesis. Plant Cell Reports, 36, 1533-1545. https://doi.org/10.1007/s00299-017-2172-6

[136] Gao, J., Wang, G., Ma, S., Xie, X., Wu, X., Zhang, X., Wu, Y., Zhao, P. and Xia, Q. (2015) CRISPR/Cas9-Mediated Targeted Mutagenesis in Nicotiana tabacum. Plant Molecular Biology, 87, 99-110. https://doi.org/10.1007/s11103-014-0263-0

[137] Wang, L., Chen, L., Li, R., Zhao, R., Yang, M., Sheng, J. and Shen, J. (2017) Reduced Drought Tolerance by CRISPR/Cas9-Mediated SIMAPK3 Mutagenesis in Tomato Plants. Journal of Agricultural and Food Chemistry, 65, 8674-8682. https://doi.org/10.1021/acs.jafc.7b02745

[138] Zhang, Y., Liang, Z., Zong, Y., Wang, Y., Liu, J., Chen, K., Qiu, J.L. and Gao, C. (2016) Efficient and Transgene-Free Genome Editing in Wheat through Transient Expression of CRISPR/Cas9 DNA or RNA. Nature Communications, 7, Article No. 12617. https://doi.org/10.1038/ncomms12617

[139] Cui, X.C. (2017) Targeted Gene Editing Using CRISPR/Cas9 in a Wheat Protoplast System. University of Ottawa, Ottawa.

[140] Kim, D., Alptekin, B. and Budak, H. (2018) CRISPR/Cas9 Genome Editing in Wheat. Functional \& Integrative Genomics, 18, 31-41. https://doi.org/10.1007/s10142-017-0572-x

[141] Wang, W., Pan, Q., He, F., Akhunova, A., Chao, S., Trick, H. and Akhunov, E. (2018) Transgenerational CRISPR-Cas9 Activity Facilitates Multiplex Gene Editing in Allopolyploid Wheat. CRISPR Journal, 1, 65-74.

https://doi.org/10.1089/crispr.2017.0010

[142] Svitashev, S., Young, J.K., Schwartz, C., Gao, H., Falco, S.C. and Cigan, A.M. (2015) Targeted Mutagenesis, Precise Gene Editing, and Site-Specific Gene Insertion in Maize Using Cas9 and Guide RNA. Plant Physiology, 169, 931-945. https://doi.org/10.1104/pp.15.00793

[143] Li, J., Meng, X., Zong, Y., Chen, K., Zhang, H., Liu, J., Li, J. and Gao, C. (2016) Gene Replacements and Insertions in Rice by Intron Targeting Using CRISPR-Cas9. Nature Plants, 2, Article No. 16139. https://doi.org/10.1038/nplants.2016.139

[144] Lee, K., Eggenberger, A.L., Banakar, R., McCaw, M.E., Zhu, H., Main, M., Kang, M., Gelvin, S.B. and Wang, K. (2019) CRISPR/Cas9-Mediated Targeted T-DNA Integration in Rice. Plant Molecular Biology, 99, 317-328.

https://doi.org/10.1007/s11103-018-00819-1

[145] Li, Z., Liu, Z.B., Xing, A., Moon, B.P., Koellhofer, J.P., Huang, L., Ward, R.T., Clifton, E., Falco, S.C. and Cigan, A.M. (2015) Cas9-Guide RNA Directed Genome Editing in Soybean. Plant Physiology, 169, 960-970. https://doi.org/10.1104/pp.15.00783

[146] Li, J.F., Norville, J.E., Aach, J., McCormack, M., Zhang, D., Bush, J., Church, G.M. and Sheen, J. (2013) Multiplex and Homologous Recombination-Mediated Genome Editing in Arabidopsis and Nicotiana benthamiana Using Guide RNA and Cas9. Nature Biotechnology, 31, 688-691. https://doi.org/10.1038/nbt.2654

[147] Danilo, B., Perrot, L., Mara, K., Botton, E., Nogué, F. and Mazier, M. (2019) Efficient and Transgene-Free Gene Targeting Using Agrobacterium-Mediated Delivery of the CRISPR/Cas9 System in Tomato. Plant Cell Reports, 38, 459-462. 
https://doi.org/10.1007/s00299-019-02373-6

[148] Gil-Humanes, J., Wang, Y., Liang, Z., Shan, Q., Ozuna, C.V., Sanchez-Leon, S., Baltes, N.J., Starker, C., Barro, F., Gao, C. and Voytas, D.F. (2017) High-Efficiency Gene Targeting in Hexaploid Wheat Using DNA Replicons and CRISPR/Cas9. Plant Journal, 89, 1251-1262. https://doi.org/10.1111/tpj.13446

[149] Li, Z., Zhang, D., Xiong, X., Yan, B., Xie, W., Sheen, J. and Li, J.F. (2017) A Potent Cas9-Derived Gene Activator for Plant and Mammalian Cells. Nature Plants, 3, 930. https://doi.org/10.1038/s41477-017-0046-0

[150] Lowder, L.G., Zhou, J., Zhang, Y., Malzahn, A., Zhong, Z., Hsieh, T.F., Voytas, D.F., Zhang, Y. and Qi, Y. (2017) Robust Transcriptional Activation in Plants Using Multiplexed CRISPR-Act2.0 and mTALE-Act Systems. Molecular Plant, 11, 245-256. https://doi.org/10.1016/j.molp.2017.11.010

[151] Piatek, A., Ali, Z., Baazim, H., Li, L., Abulfaraj, A., Al-Shareef, S., Aouida, M. and Mahfouz, M.M. (2015) RNA-Guided Transcriptional Regulation in Planta via Synthetic dCas9-Based Transcription Factors. Plant Biotechnology Journal, 13, 578-589. https://doi.org/10.1111/pbi.12284

[152] Lowder, L.G., Zhang, D., Baltes, N.J., Paul, J.W., Tang, X., Zheng, X., Voytas, D.F., Hsieh, T.F., Zhang, Y. and Qi, Y. (2015) A CRISPR/Cas9 Toolbox for Multiplexed Plant Genome Editing and Transcriptional Regulation. Plant Physiology, 169, 971985. https://doi.org/10.1104/pp.15.00636

[153] Vazquez-Vilar, M., Bernabé-Orts, J.M., Fernandez-Del-Carmen, A., Ziarsolo, P., Blanca, J., Granell, A. and Orzaez, D. (2016) A Modular Toolbox for gRNA-Cas9 Genome Engineering in Plants Based on the GoldenBraid Standard. Plant Methods, 12, 10. https://doi.org/10.1186/s13007-016-0101-2

[154] Ran, F.A., Cong, L., Yan, W.X., Scott, D.A., Gootenberg, J.S., Kriz, A.J., Zetsche, B., Shalem, O., Wu, X., Makarova, K.S., Koonin, E.V., Sharp, P.A. and Zhang, F. (2015) In Vivo Genome Editing Using Staphylococcus aureus Cas9. Nature, 520, 186-191. https://doi.org/10.1038/nature14299

[155] Steinert, J., Schiml, S., Fauser, F. and Puchta, H. (2015) Highly Efficient Heritable Plant Genome Engineering Using Cas9 Orthologues from Streptococcus thermophilus and Staphylococcus aureus. Plant Journal, 84, 1295-1305. https://doi.org/10.1111/tpj.13078

[156] Kaya, H., Mikami, M., Endo, A., Endo, M. and Toki, S. (2016) Highly Specific Targeted Mutagenesis in Plants Using Staphylococcus aureus Cas9. Scientific Reports, 6, Article No. 26871. https://doi.org/10.1038/srep26871

[157] Karvelis, T., Gasiunas, G., Young, J., Bigelyte, G., Silanskas, A., Cigan, M. and Siksnys, V. (2015) Rapid Characterization of CRISPR-Cas9 Protospacer Adjacent Motif Sequence Elements. Genome Biology, 16, 253.

https://doi.org/10.1186/s13059-015-0818-7

[158] Zetsche, B., Gootenberg, J.S., Abudayyeh, O.O., Slaymaker, I.M., Makarova, K.S., Essletzbichler, P., Volz, S.E., Joung, J., van der Oost, J., Regev, A., Koonin, E.V. and Zhang, F. (2015) Cpf1 Is a Single RNA-Guided Endonuclease of a Class 2 CRISPRCas System. Cell, 163, 759-771. https://doi.org/10.1016/j.cell.2015.09.038

[159] Zetsche, B., Heidenreich, M., Mohanraju, P., Fedorova, I. and Kneppers, J. (2016) Multiplex Gene Editing by CRISPR-Cpf1 Using a Single crRNA Array. Nature Biotechnology, 35, 31-34. https://doi.org/10.1038/nbt.3737

[160] Zhang, T., Zheng, Q., Yi, X., An, H., Zhao, Y., Ma, S. and Zhou, G. (2018) Establishing RNA Virus Resistance in Plants by Harnessing CRISPR Immune System. 
Plant Biotechnology Journal, 16, 1415-1423. https://doi.org/10.1111/pbi.12881

[161] Zhang, T., Zhao, Y., Ye, J., Cao, X., Xu, C., Chen, B., An, H., Jiao, Y., Zhang, F., Yang, X. and Zhou, G. (2019) Establishing CRISPR/Cas13a Immune System Conferring RNA Virus Resistance in Both Dicot and Monocot Plants. Plant Biotechnology Journal, 17, 1185-1187. https://doi.org/10.1111/pbi.13095

[162] Malzahn, A.A., Tang, X., Lee, K., Ren, Q., Sretenovic, S., Zhang, Y., Chen, H., Kang, M., Bao, Y., Zheng, X., Deng, K., Zhang, T., Salcedo, V., Wang, K., Zhang, Y. and Qi, Y. (2019) Application of CRISPR-Cas12a Temperature Sensitivity for Improved Genome Editing in Rice, Maize, and Arabidopsis. BMC Biology, 17, 9. https://doi.org/10.1186/s12915-019-0629-5

[163] Endo, A., Masafumi, M., Kaya, H. and Toki, S. (2016) Efficient Targeted Mutagenesis of Rice and Tobacco Genomes Using Cpf1 from Francisella novicida. Scientific Reports, 6, 38169. https://doi.org/10.1038/srep38169

[164] Lee, K., Zhang, Y., Kleinstiver, B.P., Guo, J.A., Aryee, M.J., Miller, J., Malzahn, A., Zarecor, S., Lawrence-Dill, C.J., Joung, J.K., Qi, Y. and Wang, K. (2019) Activities and Specificities of CRISPR/Cas9 and Cas12a Nucleases for Targeted Mutagenesis in Maize. Plant Biotechnology Journal, 17, 362-372. https://doi.org/10.1111/pbi.12982

[165] Tang, X., Liu, G., Zhou, J., Ren, Q., You, Q., Tian, L., Xin, X., Zhong, Z., Liu, B., Zheng, X., Zhang, D., Malzahn, A., Gong, Z., Qi, Y., Zhang, T. and Zhang, Y. (2018) A Large-Scale Whole-Genome Sequencing Analysis Reveals Highly Specific Genome Editing by Both Cas9 and Cpf1 (Cas12a) Nucleases in Rice. Genome Biology, 19, 84. https://doi.org/10.1186/s13059-018-1458-5

[166] Wang, M., Mao, Y., Lu, Y., Tao, X. and Zhu, J.K. (2017) Multiplex Gene Editing in Rice Using the CRISPR-Cpf1 System. Molecular Plant, 10, 1011-1013. https://doi.org/10.1016/j.molp.2017.03.001

[167] Yin, X., Biswal, A.K., Dionora, J., Perdigon, K.M., Balahadia, C.P., Mazumdar, S., Chater, C., Lin, H.C., Coe, R.A., Kretzschmar, T., Gray, J.E., Quick, P.W. and Bandyopadhyay, A. (2017) CRISPR-Cas9 and CRISPR-Cpf1 Mediated Targeting of a Stomatal Developmental Gene EPFL9 in Rice. Plant Cell Reports, 36, 745-757. https://doi.org/10.1007/s00299-017-2118-Z

[168] Liu, X.S., Wu, H., Ji, X., Stelzer, Y., Wu, X., Czauderna, S., Shu, J., Dadon, D., Young, R.A. and Jaenisch, R. (2016) Editing DNA Methylation in the Mammalian Genome. Cell, 167, 233-247. https://doi.org/10.1016/j.cell.2016.08.056

[169] Lei, Y., Zhang, X., Su, J., Jeong, M., Gundry, M.C., Huang, Y.H., Zhou, Y., Li, W. and Goodell, M.A. (2017) Targeted DNA Methylation in Vivo Using an Engineered dCas9-MQ1 Fusion Protein. Nature Communications, 8, Article No. 16026. https://doi.org/10.1038/ncomms16026

[170] Hahn, F. and Nekrasov, V. (2019) CRISPR/Cas Precision: Do We Need to Worry about off-Targeting in Plants? Plant Cell Reports, 38, 437-441.

https://doi.org/10.1007/s00299-018-2355-9 


\section{Abbreviations}

11N3: 11 nodulin 3

2AP: 2-acetyl-1-pyrroline

$A A D 1$ : aryloxyalkanoate dioxygenase 1

$A A T C B$ : cecropin $\mathrm{B}$ gene with a signal peptide sequence AAT from the a-1-antitrypsin

ABCC6: ATP-binding cassette sub-family $\mathrm{C}$ member 6

$A G$ : agamous gene

ALS1: acetolactate synthase 1

$B A D H 2$ : betaine aldehyde dehydrogenase 2

$B A R$ : phosphinothricin acetyl transferase

$B E L$-230. bentazon sensitive lethal 230

$B F P$ : blue fluorescent protein

Cas9. CRISPR-associated protein9 nuclease

$C C D 4 a$ : carotenoid cleavage dioxygenase $4 \mathrm{a}$

$C F P$ : cyan fluorescent protein

COMT: caffeic acid O-methyltransferase

Cre: cyclization recombination enzyme

CRISPR: clustered regularly interspaced short palindromic repeats

crRNA: CRISPR RNA

CYP97A4: cytochrome P450-type carotenoid hydroxylases 97A4

DCL1a: dicer-like 1a

DEP1: dense and erect panicle 1

DGT28: dow glyphosate tolerance

$D I P M 1:$ DspA/E-interacting protein of Malus $\times$ domestica 1

$D L$ : drooping leaf

DREB2: DRE-binding protein 1

DSB: double-strand breakage

DSM2: drought-hypersensitive mutant 2

eIF4E: eukaryotic initiation factor $4 \mathrm{E}$

EPFL9. epidermal patterning factor like 9

EPSPS: 5-enolpyruvylshikimate-3-phosphate synthase

$E R 1:$ Erysiphe pisi resistance 1

ERF922: ethylene responsive factor 922

FAD2: oleate desaturase 2

Fim: fimbrial subunit

Flp: yeast 2-micron circle plasmid recombinase

FRI: FRIGIDA

Frt: Flp-recognition target

FT4: flowering locus $\mathrm{T} 4$

GASR7: gibberellic acid-stimulated transcript-related 7

GAT: glyphosate acetyltransferase

GBSS: granule-bound starch synthase 
GFP: green fluorescent protein

GL2: GLABRA 2

GM: genetically modified

GUS: $\beta$-glucuronidase

GW2: grain width 2

$H A K 1$ : high-affinity potassium transporter 1

HIV-1: human immunodeficiency virus type 1

HPT: hygromycin phosphotransferase

HR: homologous recombination

$I d n D H:$ idonate dehydrogenase

Int: integrase

$I P K 1$ : inositol 1,3,4,5,6-pentakisphosphate 2-kinase

IPT: isopentenyl transferase

KASII: 3-ketoacyl-ACP synthase II

$L F Y$ : leafy

$L O B 1$ : lateral organ boundaries

LoxP: integration/crossover site on phage P1 genome

LTP9.4: lipid transfer protein 9.4

$L U C$ : luciferase

$M A P K 3$ : mitogen-activated protein kinase 3

$M L O$ : mildew resistance locus $\mathrm{O}$

$M T L:$ MATRILINEAL phospholipase

$M Y B 44: \mathrm{v}-\mathrm{myb}$ avian myeloblastosis viral oncogene homolog 44

$N A N O G$ : Nanog homeobox

$n C B P$ - 1: novel cap binding protein 1

NFXL1: nuclear factor-X like 1

NHEJ: non-homologous end joining

NOS: nopaline synthase

NPTII: neomycin phosphotransferase II

OCT4: octamer-binding transcription factor 4

PAM: protospacer-adjacent motif

$P A T$ : hosphinothricin acetyltransferase

PDR6: pleiotropic drug resistance 6

PDS: phytoene desaturase

$P M I$ : phosphomannose isomerase

$R F P$ : red fluorescent protein

$R L K$-798: receptor-like kinases 798

ROC5: rice outermost cell-specific gene 5

$R V D$ : repeat-variable di-residues

$R V I 6:$ resistance to Venturia inaequalis 6

SBE1: starch-branching enzyme 1

sgRNA: single guide RNA

SPL14: SQUAMOSA promoter binding protein-like 14 
SSR2: sterol side chain reductase 2

$S T F 1$ : soybean TGACG-motif binding factor 1

$S U R$ : sulfonylurea receptor

$T A L E$ : transcriptional activator-like effector

$T A L E N$ : transcriptional activator-like effector nuclease

TB1: teosinte branched 1

$T C$ : tocopherol cyclase

tracrRNA: trans-activating crRNA

$V I N V$ : vacuolar invertase

$X i s$ : excisionase

$Y F P$ : yellow fluorescent protein

$Z F$ : zinc finger

$Z F N$ : zinc finger nuclease 